\title{
A Comprehensive Review on Plant-Derived Mucilage: Characterization, Functional Properties, Applications, and Its Utilization for Nanocarrier Fabrication
}

\author{
Mansuri M. Tosif ${ }^{1}$, Agnieszka Najda ${ }^{2, *(D)}$, Aarti Bains ${ }^{3}$, Ravinder Kaushik ${ }^{4}$, Sanju Bala Dhull ${ }^{5}$, \\ Prince Chawla 1,*(D) and Magdalena Walasek-Janusz ${ }^{2}$ (D)
}

1 Department of Food Technology and Nutrition, Lovely Professional University, Phagwara, Punjab 144411, India; tosifmansuri444@gmail.com

2 Department of Vegetable Crops and Medicinal Plants, University of Life Sciences in Lublin, 20-280 Lublin, Poland; magdalena.walasek@up.lublin.pl

3 Department of Biotechnology, Chandigarh Group of Colleges Landran, Mohali, Punjab 140307, India; aarti05888@gmail.com

4 Department of Food Technology, School of Health Sciences, University of Petroleum and Energy Studies, Dehradun, Uttarakhand 248007, India; ravinderfoodtech2007@rediffmail.com

5 Department of Food Science and Technology, Chaudhary Devi Lal University, Sirsa, Haryana 125055, India; sanjudhull@gmail.com

* Correspondence: agnieszka.najda@up.lublin.pl (A.N.); princefoodtech@gmail.com (P.C.)

\section{check for}

updates

Citation: Tosif, M.M.; Najda, A.; Bains, A.; Kaushik, R.; Dhull, S.B.; Chawla, P.; Walasek-Janusz, M. A Comprehensive Review on Plant-Derived Mucilage:

Characterization, Functional Properties, Applications, and Its Utilization for Nanocarrier Fabrication. Polymers 2021, 13, 1066. https:// doi.org/10.3390/polym13071066

Academic Editor: Arn Mignon

Received: 6 March 2021

Accepted: 25 March 2021

Published: 28 March 2021

Publisher's Note: MDPI stays neutral with regard to jurisdictional claims in published maps and institutional affiliations.

Copyright: (c) 2021 by the authors. Licensee MDPI, Basel, Switzerland. This article is an open access article distributed under the terms and conditions of the Creative Commons Attribution (CC BY) license (https:// creativecommons.org/licenses/by/ $4.0 /)$.
Abstract: Easily sourced mucus from various plant parts is an odorless, colorless and tasteless substance with emerging commercial potential in agriculture, food, cosmetics and pharmaceuticals due to its non-toxic and biodegradable properties. It has been found that plant-derived mucilage can be used as a natural thickener or emulsifier and an alternative to synthetic polymers and additives. Because it is an invisible barrier that separates the surface from the surrounding atmosphere, it is used as edible coatings to extend the shelf life of fresh vegetables and fruits as well as many food products. In addition to its functional properties, mucilage can also be used for the production of nanocarriers. In this review, we focus on mucus extraction methods and its use as a natural preservative for fresh produce. We detailed the key properties related to the extraction and preservation of food, the mechanism of the effect of mucus on the sensory properties of products, coating methods when using mucus and its recipe for preserving fruit and vegetables. Understanding the ecological, economic and scientific factors of production and the efficiency of mucus as a multi-directional agent will open up its practical application in many industries.

Keywords: nanohydrogel; food applications; biopolymers; polysaccharide

\section{Introduction}

Plant-derived polymers have attained high demand in food and other industries due to their diverse industrial applications such as film coating, emulsifier, binder, and gelling agents, therefore they are excessively used in the textile industry, paper industry, and cosmetic industry $[1,2]$. Nowadays, due to the hazardous effect of synthetic polymers on human health, people showed major interest in plant-based naturally derived biopolymers (gums, mucilage, cellulose, and glucans) as an effective ingredient for the formulation of eco-friendly, sustainable, cost-effective products [3]. Moreover, a large number of polysaccharides can also be biosynthetically fabricated by several living organisms including plants, algae, animals, bacteria, and fungi [4]. Also, natural polysaccharides are used in the food industry as they are regarded as safe for human consumption [5]. Among various polysaccharides, plant-originated mucilage is widely used in various food industries due to its valuable broad-spectrum applications [6]. Generally, mucilage can be obtained from several plants or their different parts such as Aloe vera, Salvia hispanica 
seeds, Cordia dichotoma, Basella alba, Plantago psyllium, Cyamopsis tetragonoloba, Cactaceae, Abelmoschus esculentus, Trigonella foenum-graecum, Moringa Oleifera, and Linum usitatissimum. Plant-derived mucilage, due to its distinctive health (anticancer, angiotensin-converting enzyme inhibition extends to diabetes, and immunity stimulation) and food properties, is widely used as an active ingredient for the formulation of pharmaceutics, functional, and nutraceutical products [7]. Structurally, mucilage (a complex of polymeric polysaccharide) is mainly composed of carbohydrates with highly branched structures that consist of monomer units of L-arabinose, D-xylose, D-galactose, L-rhamnose, and galacturonic acid. They also contain glycoproteins and different bioactive components such as tannins, alkaloids, and steroids [8-10]. Also, mucilage produces an indefinite number of monosaccharides on hydrolysis, depending on the type of hydrolysis products obtained due to the nature of the polysaccharide. It can also further classify into pentose sugars (xylan) and hexose sugars (cellulose and starch) and can be considered as gum like components due to their similar physiological properties. However, both mucilage and gum are mostly related to hemicelluloses in composition, except the sugars produced by hemicelluloses such as xylose, glucose, and mannose instead of sugars produced by the gums such as galactose and arabinose [11,12]. Moreover, that can be utilized in several applications such as edible coating, wound healing, tablet formation, encapsulation, water purification, and various nanocarriers. Mucilage exhibits an excellent functional property, however, due to the hydrogen bonding in between different functional and other polar groups, they also have an important role in film, emulsion, coated metal nanoparticles, and gel formation [13]. In recent years, nanostructured hydrogels and mucilage coated metal nanoparticles are intensively used as a significant delivery vehicle for various hydrophilic and hydrophobic components [14]. For the formulation of nanohydrogel, different types of biopolymers and cross-linking polymers can be used and mucilage can act as either a primary biopolymer or a cross-linking component for the formulation of nanohydrogel [15]. Several reports have been published on the formulation of stable nanohydrogels using mucilage as an active component and researchers revealed various therapeutic and food applications of the formulated nanohydrogels [11-17]. Furthermore, nanohydrogels formulated with mucilage exhibit higher stability than that of other conventional plant-based biopolymers. Furthermore, metal nanoparticles coated with polymeric carbohydrates such as starch, dextran, chitosan, and mucilage are the most abundant nanocarriers used for targeted drug delivery. Because, in addition to increasing blood circulation time by hiding them from the immune system, their polymeric shells enable them to transfer and release the drug during biodegradation $[16,17]$. However, only a few reports are published on the comprehensive knowledge of plant-derived mucilage, therefore, the present review is emphasized on the physicochemical properties, characterization, health, and functional attributes of the mucilage. Also, the application of mucilage crosslinked nanohydrogels and mucilage coated metal nanoparticles are discussed with mechanisms and schematic diagrams.

\section{Origin of Mucilage in Different Plant Parts}

The Mucilage is a water-soluble edible adhesive material that constitutes carbohydrates and uranic acids units present in different parts of plants including the mucous epidermis of the outer layer of seeds, bark, leaves, and buds [18]. The majority of plants produce mucilage from the seed coat and this process of producing mucilage is termed Myxospermy and some plant species produce it from the fruit epicarp which is known as Myxocarpy. Plants producing mucilage from seed coat belong to the family Plantaginaceae, Acanthaceae, Linaceae, and Brassicaceae, while Myxocarpy (fruit mucilage) is commonly found in families like Poaceae, Asteraceae, and Lamiaceae [19]. The presence of mucilage on the seed coat prevents the plant from early seedling development and drought stress during the germination. depending upon its origin it is characterized into many groups including hair secretion, intracellular mucilage, and cell membrane mucilage [11]. The mucilage obtained from the seed coat is classified into three classes that are endosperm 
non-starch polysaccharide (galactomannans), cell wall material of the endosperm (soybean hemicelluloses and xyloglucans), and mucilaginous constituents of the seed coat (flaxseed, Chia seed, and yellow mustard) [20,21]. Mucilage develops a jelly-like structure around fruit and maintains moisture and prevents seeds from completely drying out and therefore act as a hydrating agent and also acts as an energy reservoir [22,23]. Mucilage also plays a significant role in the control of germination, the promotion of dispersal, and soil adhesion, root mucilage is usually exhibited from the outer layers of the root cap, consisting of mostly root border cells and polysaccharides, which produce various chemical substances such as flavonoids, phenolics acids, amino acids, galactosidase, antibiotics, sugars, peroxidase, proteins, and anthocyanins [24]. Moreover, root mucilage plays a very important role for plant growth, such as for the maintenance of root-to-soil touch, root tip lubrication, soil microaggregate stabilization, water storage ability, selective storage, and the absorption of ions $\left(\mathrm{Na}^{+}, \mathrm{Cd}^{2+}, \mathrm{Pb}^{2+}\right.$, and $\left.\mathrm{Al}^{3+}\right)$ through root cells. Furthermore, it is primarily secreted by the secretory vesicles of hypersecretory root cap cells as a coagulated polysaccharide (poly-galacturonic acid) and is subsequently passed during root extension to older root areas, but epidermal cells are also effective in secreting mucilage [25-27]. Mucilage is also produced in the leaves and buds of several plant species; it may allow the leaves to retain water capacity when soil water deficits emerge; therefore, it helps in the storage of food and water. Various mucilage containing plants and their origins are highlighted in Table 1.

Table 1. Origin of mucilage in different parts of a plant.

\begin{tabular}{|c|c|c|c|c|}
\hline Source of Mucilage & Part & Yield of Mucilage & Extraction Method & References \\
\hline Linum usitatissimum L. & Seed & $7.3 \%$ & Extracted by centrifugation & [28] \\
\hline Spinacia oleracea L. & Leaves & $12.62 \%$ & Extracted by acetone & [29] \\
\hline Salvia hispanica & Seed & $\begin{array}{l}8.3 \% \\
6.4 \%\end{array}$ & $\begin{array}{l}\text { Non-thermal extraction } \\
\text { Thermal extraction }\end{array}$ & [30] \\
\hline Plantago major & Seed & $15.18 \%$ & Thermal extraction & [31] \\
\hline Basella alba & $\begin{array}{l}\text { Leaves } \\
\text { Stem }\end{array}$ & $\begin{array}{l}4.83 \% \\
6.20 \%\end{array}$ & Hot water extraction & [32] \\
\hline Psyllium seed & Husk & $37-52 \%$ & Ultrasonic bath extraction & [33] \\
\hline
\end{tabular}

\section{Extraction of Plant-Derived Mucilage}

Mucilage can be extracted from any part of the plant is considered a valuable natural polysaccharides source with excellent potential in pharmaceutical and food applications. several studies said that the yield, functional, and rheological properties of mucilage are highly dependent on the extraction method and extraction conditions [28]. Generally, all the extraction method of mucilage comprises of two successive procedures which are maceration and precipitation. Usually, the maceration extraction method of mucilage is simple and valuable, although the disadvantage of maceration is low efficiency and long extraction time [33]. This method consists of soaking the raw material in the chosen solvent at room temperature with regular agitation. maceration for extraction of mucilage is typically done using the low ratio of solid-liquid and hot water treatment. acid solutions, ammonium oxalate, and EDTA are also used to improve mucilage extraction [26]. According to several studies, the water-extracted mucilage showed high viscosity than alkali and acid-extracted mucilage due to marked differences in the mucilage structure of monosaccharides. However, the limitations of these methods are higher levels of protein with low yields of mucilage and subsequent denaturation. Apart from its nutritional value, protein is known as an impurity in the final product which affects its purity and restricts its industrial use due to the instability and undesirable taste caused by microbial spoilage. while protein presence in the mucilage has been identified regardless of the extraction methods used and an emulsifying action has been taken to demonstrate that protein is desirable to improve the texture and consistency of emulsions and beverages [34]. The general outline revealed an increase in protein levels as time and temperature of maceration increased, resulting in a higher molecular weight of mucilage. Also, higher maceration 
temperature and extended stirring period contributed to highly colored mucilage, which is unacceptable for industrial usage. Acid pre-treatment should be considered in order to protect against this color effect [35]. Solvent treatment is a conventional extraction technique of mucilage. generally, the aqueous procedure included the mucilage extracted from the dry parts of the plant (seeds, leaves, roots, stems) by using hot distilled water. The procedure occurs under continuous shaking and stirring of solution. The solution is then filtered, these stages can be repeated often. Consequently, the mucilage is precipitated by the addition of alcohol to the filtrate. Then, precipitated mucilage is dried via freeze-drying or in an oven to obtaining the final mucilage powder [29] whereas ultrasonication treatment is a emerging non-thermal technique for mucilage extraction with several applications in the pharmaceutical and food industry. Furthermore, in some plant parts, two layers of mucilage (Arabidopsis seed coating) make the extraction process very difficult; therefore, ultrasonication treatment can be much helpful in such cases. The outer layer of the seed coat can be extracted through shaking, and an inner layer of the seed coat is composed of rhamnogalacturonan I, which is a very difficult challenge to extract. in this case, ultrasonic treatment for $20 \mathrm{~s}$ showed excellent results. ultrasound with low-frequency has been used for mucilage extraction by disrupting the biological cell wall through the formation of pores. The formation of cavitation bubbles and their resulting collapse produce high spots with higher pressure and temperature, capable of breaking the bonds between the mucilage and seed coat. As a result, the amplitude of the ultrasounds, extraction temperature, and time must all be selected carefully to prevent the extraction of undesirable compounds and mechanical disturbance of the seeds [36]. Likewise, microwave is a thermal emerging extraction method that can be used for the extraction of mucilage from several parts of the plant. Moreover, microwave-assisted extraction is a potential alternative method providing advantages in terms of improved extraction efficiency, reduced solvent consumption, and time reduction. Conventional aqueous extraction methods include the effects of solvent, $\mathrm{pH}$, and temperature, which change the nutritional value, functional and structural property of mucilage [37]. Using hot water extraction with a long extraction period is considered to be cost-effective, although it can reduce the consistency of the mucilage. Several studies said that conventional hot water extraction methods result in the loss of heat liable compounds of mucilage, to overcome this major drawback, microwave-assisted extraction with extraction at 300 to $400 \mathrm{~W}$ for 120 to180 s was used, resulting in a high mucilage yield. Consequently, enzymes also play a very crucial role in the extraction process due to their wide range of applications in the food industry. During the enzymatic hydrolysis for reduction of viscosity and molecular weight of mucilage, several enzymes can be used such as rhamnase, arabinase, xylanse, and mannonase [13]. Furthermore, cold extraction can be applied in order to produce more viscous mucilage, which is more natural but with a lower yield compared to the hot extraction method [38]. Moreover, an increase in the ratio of solid-liquid is proportional to more yield due to more availability of solvents, which improves the driving force of mucilage from raw plant material. However, the high ratio of solid-liquid cannot significantly affect mucilage yield, also consisting of high process costs. In this context, Elboutachfaiti et al. [37] extracted mucilage from flaxseed mucilage after maceration in hot water, six rhamnogalacturonan fractions of flaxseed mucilage were extracted and purified by using ion-exchange chromatography. As regards the $\mathrm{pH}$ effect on the extraction yield of mucilage, a significant increase in the yield of mucilage was observed with an increase in $\mathrm{pH}$ due to the separation of the acidic groups such as uranic acids, and due to the attraction between the negatively charged ones, which increased the solubility of the mucilage, although further decreased after a certain $\mathrm{pH}$ value. Moreover, lower $\mathrm{pH}$ values of mucilage are likely to improve protein recovery due to protein solubilization. Although, below $3 \mathrm{pH}$, the action of acid can result in a lower protein yield due to its hydrolysis [39]. In order to obtain the quality polysaccharides (mucilage) and highest yield, it is necessary to improve the extraction procedure (Figure 1). Deionized water can also be used for the extraction of mucilage [39,40]. 


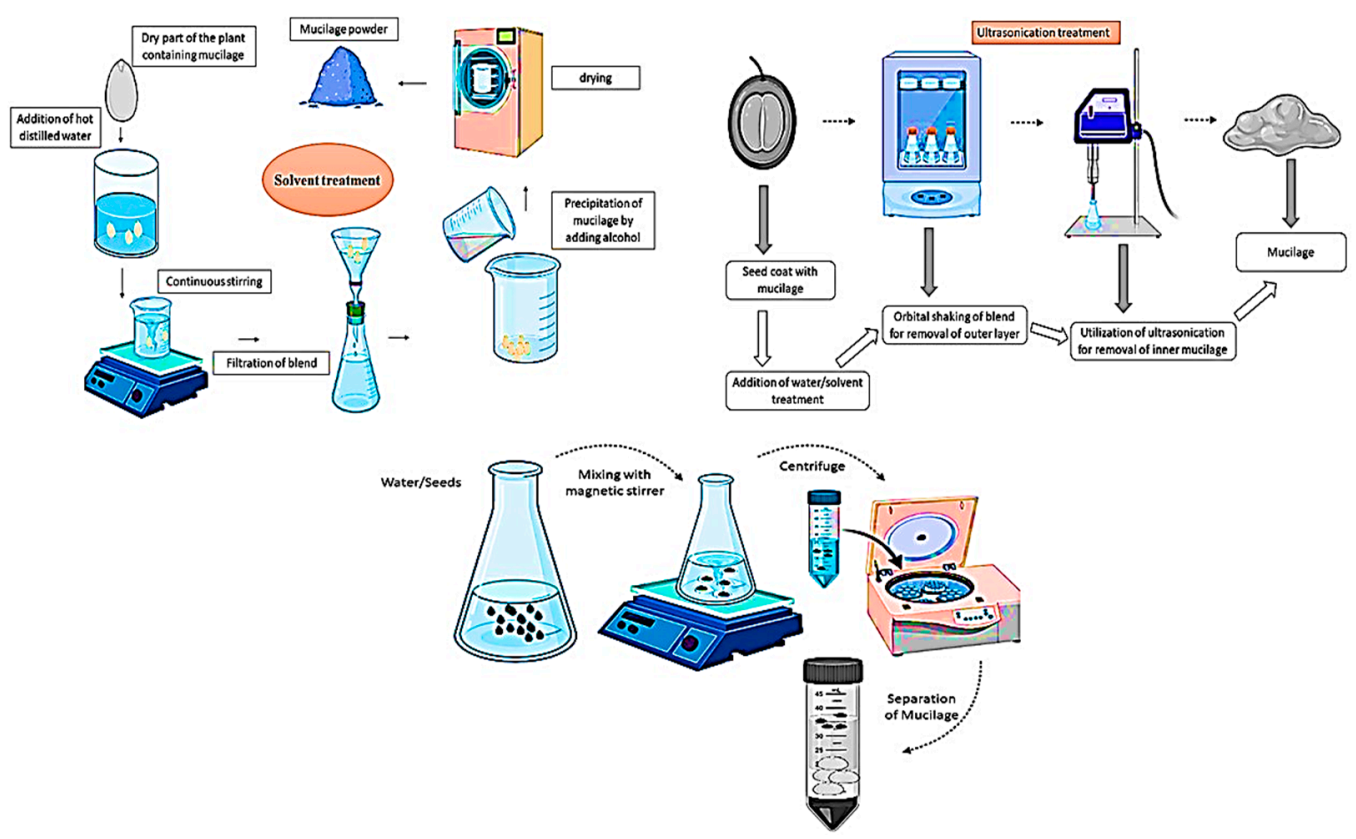

Figure 1. Extraction of mucilage from plant parts using solvent extraction, microwave assisted, and centrifugation process.

\section{Structural Chemistry of Mucilage}

The mucilage is a water-soluble component constituting different functional chemical components with potential human health benefits [41]. Mucilage and gum are a subgroup of hydrocolloids containing monosaccharides linked with organic acids and are close to each other due to the hydrophilic and hydrocolloid components that create a sticky solution or gel in the presence of water [2]. Plant hydrocolloids (Gum and mucilage) contain pentose, galactose and methyl pentose sugar joined to uranic acid residues by glycosidic linkages. The terminal atom of carbon (at the opposite side of the carbonyl chain) of the monosaccharide unit may occur in an oxidized (carboxylic acid) form. Six carbon with aldohexose in the form of a carboxylic acid is termed uranic acid [24]. Furthermore, Monosaccharides are the most common carbohydrate molecules that cannot be broken down into simpler sugar molecules by hydrolysis and are occasionally referred to as simple sugars. Mucilage present in plant consists of two main polysaccharides pectin and hemicellulose each of which is comprised of rhamnogalacturonan, and arabinoxylans respectively [42]. Generally, mucilage arabinoxylans encompass by $\beta$-1,4-linked xylose backbones, they are mostly replaced by 1-3 sugar residues at $\mathrm{O}-2$ or / and O-3 positions. While, mucilage rhamnogalacturonan I (RG-I) comprise a backbone of the repeating disaccharide of $\alpha$-(1,2)-rhamnose and $\alpha$-d-(1,4)-galacturonic acid [43]. Moreover, there is some evidence that rhamnogalacturonan I side chains can be covalently bound to hemicelluloses, creating a super-macromolecular polymeric network. The neutral sugars are mainly D-xylose, L-arabinose, and D-galactose, with the proportions and types of neutral sugars varying with the origin of mucilage. In mucilage, both carboxyl and hydroxyl groups are present as functional groups due to the presence of these functional groups it acts as a polyelectrolyte [44]. The different chemical structures of polysaccharides are illustrated in Figure 2. 

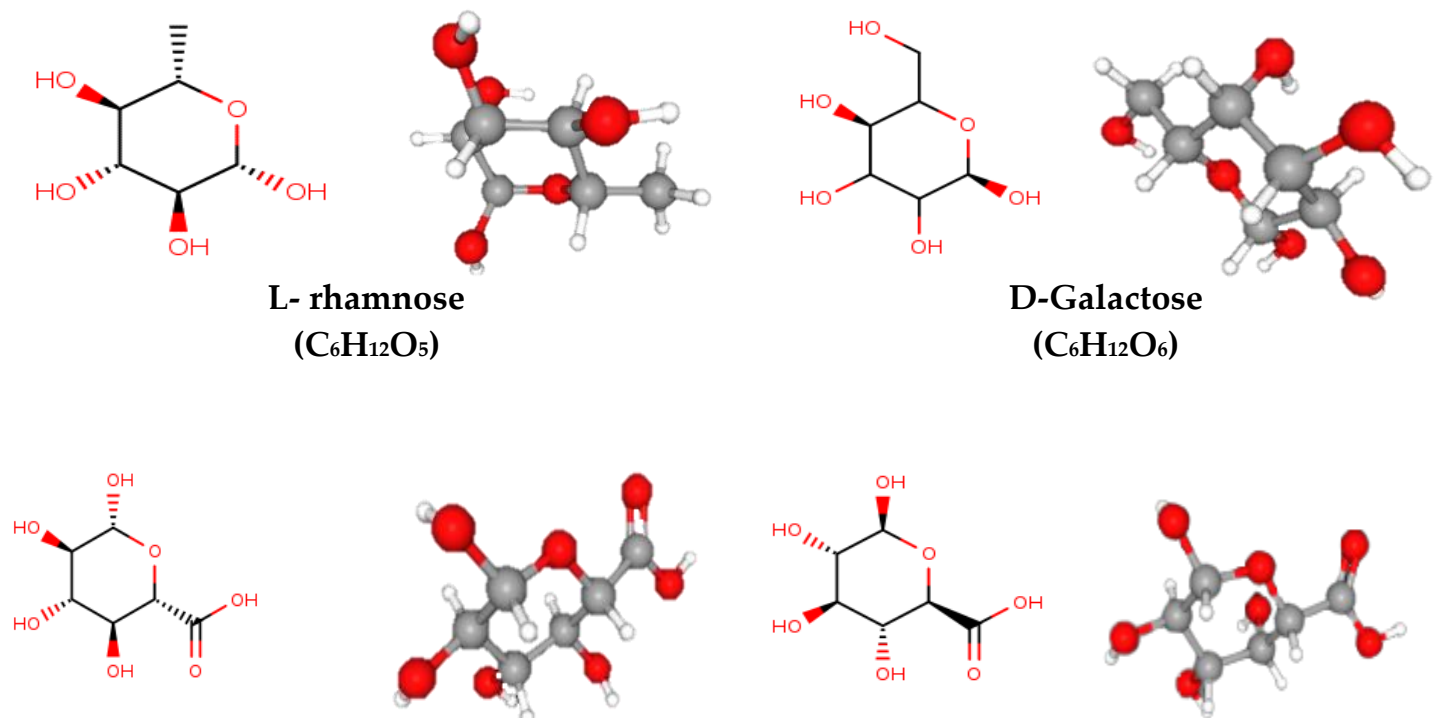

\section{D-Glucuronic acid} $\left(\mathrm{C}_{6} \mathrm{H}_{10} \mathrm{O}_{7}\right)$

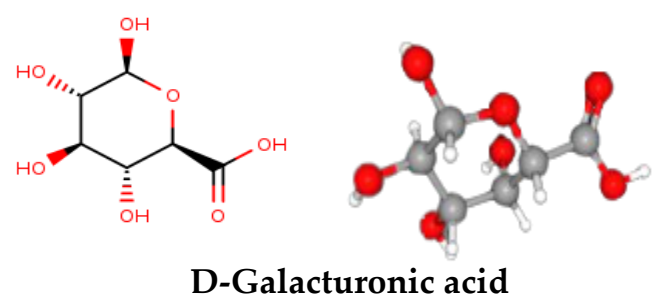

$\left(\mathrm{C}_{6} \mathrm{H}_{10} \mathrm{O}_{7}\right)$

Figure 2. Chemical structure of different mucilage (L- rhamnose $\left(\mathrm{C}_{6} \mathrm{H}_{12} \mathrm{O}_{5}\right)$ 6-deoxy-hexose or methyl-pentose, D-Galactose $\left(\mathrm{C}_{6} \mathrm{H}_{12} \mathrm{O}_{6}\right)$ C-4 epimer of glucose, D-Glucuronic acid $\left(\mathrm{C}_{6} \mathrm{H}_{10} \mathrm{O}_{7}\right)$ sixth carbon atom oxidized to a carboxylic acid, DGlucuronic acid $\left(\mathrm{C}_{6} \mathrm{H}_{10} \mathrm{O}_{7}\right)$ an aldehyde group at $\mathrm{C} 1$ and a carboxylic acid group at $\left.\mathrm{C6}\right)$.

In a study done by Hosseini-Parvar et al. [45], Beikzadeh et al. [9], Timilsena et al. [46], and Mirhosseini et al. [47] observed that basil seed mucilage contains xylan (24.29\%), glucan $(2.31 \%)$, and glucomannan $(43 \%)$, chia seed contains glucose $(19.6 \%)$, galactose $(6.1 \%)$, arabinose $(9.6 \%)$, xylose $(38.5 \%)$, galacturonic acid $(5.3 \%)$, and glucuronic acid $(18.7 \%)$, cress seed mucilage contains glucose $(1 \%)$, fructose $(6.8 \%)$, arabinose $(19.4 \%)$ rhamnose $(1.9 \%)$, glucuronic acid $(6.7 \%)$, and galactose $(4.7 \%)$, and flaxseed contains xylose (21.1-37.4\%), fructose (5-7.1\%), galactose (20-28\%), and arabinose (9.2-13.5\%) [17]. All these studies conclude that mucilage present in the seeds coat of plants of different species exhibits different forms of carbohydrates and uranic acid units.

\section{Characterization of the Mucilage}

This technique is used to determine the chain configuration, i.e., the microstructure of the polymer when present in either a solid state or a liquid state. This technique can also be applied to any form of the sample containing a spin-filled nucleus. In this context, Singh et al. [2] observed nuclear magnetic resonance spectra $\left({ }^{1} \mathrm{H}\right.$ and $\left.{ }^{13} \mathrm{C}\right)$ of the mucilage of the seed/fruit of Diospyros melonoxylon Roxb at $400 \mathrm{MHz}$, and revealed that many sugar compositions are consist of $\mathrm{CH}$ and $\mathrm{OH}$ groups of mannose ( $\delta 3065$ to $\delta 3060 \mathrm{ppm}$ ), $\mathrm{CH}$ group of rhamnose ( $\delta 72.2 \mathrm{ppm}), \mathrm{CH}$ group of arabinose $(\delta 70.1-\delta 71.8 \mathrm{ppm})$, the $\mathrm{CH}_{2}$ group of arabinose ( $\delta 3.81$ to $\delta 3.55 \mathrm{ppm})$, and the $\mathrm{CH}$ group of mannose ( $\delta 72.3 \mathrm{ppm})$, respectively. Likewise, Deore et al. [48] and Dehghani et al. [49] studied the composition of the mucilage of Cassia obtusifolia and chia seeds and concluded that the mucilage of Cassia obtusifolia contains the $\mathrm{CH}$ group of arabinose $(\delta 69.61-\delta 71.25 \mathrm{ppm})$, glucose $(\delta 4.15$ and $\delta 3.84 \mathrm{ppm}), \mathrm{OH}$ and $\mathrm{CH}$ groups of mannose (d 3.62 and $\mathrm{d} 3.41 \mathrm{ppm})$, methyl group $(1.23 \mathrm{ppm})$, non-anomeric protons ( 3.1 and $4.1 \mathrm{ppm}), \mathrm{OH}$ and $\mathrm{CH}_{2}$ groups of arabinose ( $\delta$ 3.55 and $\delta 3.39 \mathrm{ppm}$ ), while chia seed mucilage contains $\mathrm{OH}$ and $\mathrm{CH}$ groups of mannose (3.6 and $3.65 \mathrm{ppm}$ ), $\mathrm{OH}$ and $\mathrm{CH}$ groups of arabinose (3.55 and $3.81 \mathrm{ppm}$ ), and the bond between methyl and protons with $\mathrm{C}_{6}$ and $\mathrm{C}_{4}$ of galactose. In another study done by Devi et al. [50], it was observed that flaxseed mucilage contains methylene and thio portions of thioglycolate resonance at the peak value of 4.14 and $5.56 \mathrm{ppm}$. FTIR analysis is performed to determine chemical structure and functional groups of mucilage, FTIR spectroscopy can be used in wavelength regions between 4000 and $400 \mathrm{~cm}^{-1}$ at a resolution of $2 \mathrm{~cm}^{-1}$ or $4 \mathrm{~cm}^{-1}$. The area between 800 and $1200 \mathrm{~cm}^{-1}$ is known as the carbohydrate fingerprinting 
area. Mucilage contains polymers such as $\mathrm{CH}_{2}, \mathrm{O}-\mathrm{H}, \mathrm{C}-\mathrm{H}, \mathrm{C}-\mathrm{O}-\mathrm{C}$, and the carboxylate group was observed in different studies. It was also observed that the spectra obtained from mucilage showed a huge peak value at the range of $3500-3300 \mathrm{~cm}^{-1}$, the absorption band at around $3000-2800 \mathrm{~cm}^{-1}, 1270-1080 \mathrm{~cm}^{-1}$, at $1600 \mathrm{~cm}^{-1}$, and $1400 \mathrm{~cm}^{-1}$ confirming the vibrational stretching of the polymeric $\mathrm{O}-\mathrm{H}$ group, $\mathrm{CH}_{2}$ and $\mathrm{C}-\mathrm{H}$ group, $\mathrm{C}-\mathrm{O}$ group, Carboxylate asymmetric stretching, and symmetric stretching respectively [51-53]. NajiTabasi et al. [54] conducted a study on basil seed mucilage, the FTIR analysis of the study indicated the existence of uronic acids, absorptions at wavelengths 1600 and $1400 \mathrm{~cm}^{-1}$ confirmed the presence of uronic acid assigned to C-OO asymmetrical and symmetrical stretching, respectively. Consequently, Pratik and Shadique [55] extracted mucilage from the fruits of Tilkor (Mamoradica monadelpha), the mucilage sample was prepared in powder form by using freeze-drying. FTIR result confirmed the presence of complex carbohydrate (starch), moreover, FTIR of Tilkor mucilage showed the vibrational stretching of $\mathrm{C}-\mathrm{H}$ bending of Alkynes, $\mathrm{C}-\mathrm{H}$ bending in aromatic rings, C-C Stretching vibrations, free $\mathrm{O}-\mathrm{H}$ groups Vibrations, and $\mathrm{C}=\mathrm{N}$ bond showed Aminoacids/ proteins and the absorption band wavelength at around $685 \mathrm{~cm}^{-1}-665 \mathrm{~cm}^{-1}, 900 \mathrm{~cm}^{-1}-625 \mathrm{~cm}^{-1}, 822 \mathrm{~cm}^{-1}, 3710-3513 \mathrm{~cm}^{-1}$, and $1623 \mathrm{~cm}^{-1}$ respectively.

Rheological characterization is used to determine the shear rate-dependent flow behavior of the mucilage solutions, and is generally examined over a shear rate range of 0 to $100 \mathrm{~Hz}$. The rheological characterization of the mucilage of seeds from different plants was performed by several scientists. In this context, Punia et al. [56] measured the rheological characteristics of the mucilage of chia seeds by an oscillatory shear (range of frequency stress sweep is about $1 \mathrm{~Hz}$ to $10 \mathrm{~Hz}$ ) and revealed the highest correlation coefficient of chia seed $\left(R^{2}>98.58\right)$ and with the increase in shear rate, they observed a rapid decrease in the viscosity of the solution. In another study by Capitain et al. [57] it was observed that the chia seed dispersions viscosity increases by increasing the concentration from a range of 0.25 to $1.00(w / v)$. Likewise, Abbastabar et al. [58] characterized quince seed mucilage and observed curve turned from the linear range at strain $11.4 \%$. Increases of storage modulus and decrease of viscoelastic linear range $(7.7 \%)$ were observed in the presence of $0.2 \mathrm{M} \mathrm{NaCl}$ as NaCl shows its dual behavior on the mucilage or gum. Quince seed mucilage has high activation energy which is about $6988.74 \mathrm{~J} \mathrm{~mol}^{1}$. activation energy is usually used to determine the chain flexibility of biopolymers. Keshani-Dokht et al. [59] in their study observed a decrease in the magnitude of Cordia myxa mucilage and an increase in solution concentration from 0.99 to 0.89 and $0.2-2 \%$ respectively. In their study, they observed that the mucilage solution has a tendency of more shear thinning at a high concentration level. The activation energy of Cordia myxa mucilage was calculated at about $446.23 \mathrm{KJ}$. The thermogravimetry analysis (TGA) technique is used for measuring the mass variation in a particular mucilage-containing sample as a function of temperature in a stable atmosphere [53]. The vibration of mass can be negative when the part of the sample is transformed in vapor and that can be positive when the sample is subjected to corrosion or oxidation [60]. The thermal stability of mucilage can be measured in two conditions such as isothermal (temperature is kept constant) and dynamic (temperature is increased at a linear rate) [6]. Thermal stability and thermal behavior of Manilkara zapota (Linn.) Seed mucilage data showed that heating at $10^{\circ} \mathrm{C} / \mathrm{min}$ from $0{ }^{\circ} \mathrm{C}$ to a maximum of $900{ }^{\circ} \mathrm{C}$ resulted in two mass loss events according to the derivative thermograms and primary thermograms. Furthermore, there was $41.17 \%$ weight loss at $178.6-359.7^{\circ} \mathrm{C}$ temperature range in the first Decomposition stage and $30.06 \%$ weight loss at $359.7-600.6^{\circ} \mathrm{C}$ in the second Decomposition stage. Besides, at the same temperature range the enthalpy (315.8729 and $3624.787 \mathrm{~J} / \mathrm{g})$, DTG peak $\left(350.3^{\circ} \mathrm{C}\right.$ and $\left.614.4^{\circ} \mathrm{C}\right)$, and heat change (138.4354 and $1082.215 \mu \mathrm{Vs} / \mathrm{mg}$ ) were observed for both first and second decomposition stages [61]. Differential scanning calorimetry (DSC) has emerged as an excellent physical technique to investigated physical and chemical or exothermic and endothermic changes that occur in the mucilage during thermal processing [62]. The high thermo-stable property of mucilage can be utilized in paints for stabilizing suspensions or emulsions, improve bake-stability in 
cakes, preventing crystal growth, and improving freeze-thaw stability [6]. The outcome of the DSC analysis of Diospyros melonoxylon Roxb seed mucilage discovered the glass transition temperature is $78^{\circ} \mathrm{C}$. the high intense peak was observed in Differential scanning calorimetry thermograms at around $200{ }^{\circ} \mathrm{C}$ which was an endothermic transition. The large endothermic peak correlates to the hydrophilic nature of the functional groups of chia seed mucilage and can be due to in regular packing structure of the gums [63]. The endothermic peak transition temperatures (Te, To, Tp) of chia seed mucilage were $215^{\circ} \mathrm{C}, 52.8^{\circ} \mathrm{C}$, and $107.9^{\circ} \mathrm{C}$, respectively. $233.9 \mathrm{~J} / \mathrm{g}$ was enthalpy change value of chia seed mucilage. In the case of exothermic peak transition temperatures ( $\mathrm{Te}, \mathrm{To}, \mathrm{Tp}$ ) of chia seed mucilage were $354.9^{\circ} \mathrm{C}, 277.7^{\circ} \mathrm{C}$, and $316.8^{\circ} \mathrm{C}$, respectively, and the enthalpy value of exothermic peak $(101.9 \mathrm{~J} / \mathrm{g})$ was lower than endothermic. The high enthalpy value of mucilage indicates high energy needed in releasing water-related with the loss of crystallization as well as hydrogel bounded [56].

\section{Functional Properties of Mucilage}

Hydrocolloid polymers in the food industry and pharmaceutical industry are generally made up of large molecular biopolymers. A biopolymer contains a hydroxyl group which leading to viscous dispersions, increases the water attraction. Also, those hydrocolloids are widely used as a stabilizer, thickener, dietary fiber, whipping agent, and fat replacer. Moreover, they also have applications in crystallization inhibition, edible coatings, edible films, and encapsulating flavors $[13,64]$. The different functional properties of mucilage are shown in Table 2.

Table 2. Functional properties of various plant-based mucilage.

\begin{tabular}{|c|c|c|}
\hline Mucilage Source & Functional Property & References \\
\hline Chia seed mucilage & $\begin{array}{l}\text { Stabilizing agent, thickening agent, fat } \\
\text { replacer, and emulsifying agent. }\end{array}$ & {$[21,56]$} \\
\hline Okra seed mucilage & $\begin{array}{l}\text { Oil absorption, water absorption, } \\
\text { emulsion stability, foaming capacity, } \\
\text { and emulsifying capacity. }\end{array}$ & {$[65,66]$} \\
\hline Tamarind seed mucilage & $\begin{array}{l}\text { Water holding capacity, oil holding } \\
\text { capacity, and solubility. }\end{array}$ & {$[13,67]$} \\
\hline Flaxseed mucilage & $\begin{array}{l}\text { Water holding capacity, thickening } \\
\text { agent, gelling agent, emulsifying agent, } \\
\text { and foaming agent. }\end{array}$ & {$[40,68,69]$} \\
\hline Cress seed mucilage & $\begin{array}{l}\text { water absorption, Film-forming agent, } \\
\text { and gelling agent. }\end{array}$ & [70] \\
\hline
\end{tabular}

\subsection{Water Holding Capacity of Mucilage}

All the scientific literature has shown that high water holding capacity is due to the presence of hydroxyl groups and protein substituents in the gum and mucilage structure. In 1996, the Food and Agriculture Organization of the united nation (FAO) described it as a potential source of polysaccharides due to its excellent property in aqueous solutions at low concentrations [63]. Water holding capacity is the capacity of a moist polymer or sample to hold water when exposed to an external centrifugal gravity force or compression. It comprises the sum of linked water, physically trapped water, and hydrodynamic water, the latter of which contributes most to this capacity [13]. The low amount of water holding capacity can be attributed to the high solubility of mucilage even at a high concentration which leads to an inability to form a gel. Furthermore, mucilage is widely selected in the food system (fruits, vegetables, poultry, and fish) and contributed to improved emulsifying and water binding capacity of food [60]. According to a study the water holding capacity of Cordia myxa mucilage $(14.94 \pm 2.44 \mathrm{~g} / \mathrm{g})$, Opuntia dilleniid mucilage $(4.00 \pm 0.10 \mathrm{~g} / \mathrm{g})$, sweet basil seed mucilage $(97.5 \pm 2.4 \mathrm{~g} / \mathrm{g})$, Tamarind seed at $25^{\circ} \mathrm{C}(0.18 \pm 0.014 \mathrm{~g} / \mathrm{g})$, at $45^{\circ} \mathrm{C}$ $(0.22 \pm 0.167 \mathrm{~g} / \mathrm{g})$, and at $65^{\circ} \mathrm{C}(1.07 \pm 0.025 \mathrm{~g} / \mathrm{g})$, which is shown that the water holding capacity of tamarind seed is increasing as increasing of temperature $[13,26,59,71,72]$. 


\subsection{Oil Holding Capacity of Mucilage}

Oil holding capacity is the most important functional property of hydrocolloids, which indicates oil absorption capacity. According to the reports, due to an increase in the accessibility of nonpolar chains with increasing molecular mobility of hydrophobic hydrocarbon domains, plant-derived mucilage show increased oil binding capacity with increases in temperature. The oil holding capacity of tamarind seed mucilage at $25^{\circ} \mathrm{C}$ $(0.068 \pm 0.014 \mathrm{~g} / \mathrm{g})$, at $45{ }^{\circ} \mathrm{C}(0.104 \pm 0.010 \mathrm{~g} / \mathrm{g})$, at $65^{\circ} \mathrm{C}(0.133 \pm 0.004 \mathrm{~g} / \mathrm{g})$; chia seed mucilage $(12.97 \pm 1.90 \mathrm{~g} / \mathrm{g})$; guar gum $(0.87 \pm 0.06 \mathrm{~g} / \mathrm{g})$; and basil seed mucilage $(8.37 \pm 1.02 \mathrm{~g} / \mathrm{g})[13,26,27,73,74]$. Good oil holding values indicate that mucilage could improve the texture of food products. Fruit or seed extracted mucilage has good oil binding capacity due to presence of monopolar molecules, therefore, it can trap higher amounts of oil particles and also prevent oil and the loss of flavor from food systems. Therefore, fruit or seed-derived mucilage can be used as a good functional ingredient in formulated foods [75].

\subsection{Emulsifying Property of Mucilage}

Plant-derived polysaccharides such as gum, mucilage, and starch as well as Carboxymethyl cellulose (CMC) are widely used in emulsion products [76,77]. Polysaccharide mucilage and gum are attracting attention towards commercial use in the pharmaceutical and food industry due to their excellent emulsifying properties, where they are used for suspension of particulates, stabilization of emulsions, control of crystallization, the thickening, and formation of films, encapsulation [30]. The emulsion products prepared from different plants are checked for their stability by several scientists to use them for different purposes in different food and pharmaceutical industries. Sangeethapriya and Siddhuraju [78] prepared the emulsion products from quince seed mucilage and they observed that the stability of the resulting product was $94.89 \%$ likewise Behrouzian et al. [79] observed the high emulsifying capacity (92\%) of cress seed mucilage while in another study by Jouki et al. [80] it was observed that emulsifying capacity of Zizyphus mauritiana fruit mucilage is about $54.12 \%$ and emulsifying stability is $42.14 \%$.

\subsection{Foaming Property of Mucilage}

Good foaming property is associated with the elastic structure of the mucilage, foaming property of mucilage is depending upon many factors, such as the presence of further compounds in the hydrocolloid, molecular weight, protein, structure, and carbohydrates. The good foaming capacity of mucilage is highly associated with the flexible structure of mucilage that can reduce the surface tension [81]. The foaming capacity and foaming stability of Abelmoschus esculentus mucilage is $50-51 \%$ to $50-62 \%$ and $36.04 \%, 1 \%$ w/v respectively, foaming capacity flaxseed mucilage reported about $75 \%$, and Plantago seed mucilage has foaming stability $(88.4 \%)[13,66,82]$.

\subsection{Antioxidant Property of Mucilage}

Plant-derived polymers contain different phenolic compounds including flavonoids and polyphenols as bioactive compounds. These bioactive compounds prevent the chain propagation reactions originated by free radical reactions and prevent disease-related oxidative damage [83-86]. Sangeethapriya and Siddhuraju [78] studied the antioxidant activity of the polyphenols isolated from Zizyphus mauritiana fruit mucilage against DPPH2,2-diphenyl-1-picrylhydrazyl is $5.27 \mathrm{~g}$ mucilage/g DPPH, superoxide is $85.12 \%$, ABTS2,2-azino-bis-3-ethylbenzothiazoline-6-sulphonic acid is $16587.32 \mathrm{mmol}$ Trolox Eq./g, and hydroxyl is $76.13 \%$. Sardarodiyan et al. [87] also studied the antioxidant activity and total phenolic compounds of Lallemantia royleana seed mucilage and in their study, they observed antioxidant activity of $528.54 \mu \mathrm{g} / \mathrm{mL}$ of DPPH and total phenolic content of $82.56 \pm 1.6 \mu \mathrm{g} / \mathrm{GAE}$. In two different studies done by Jouki et al. [80] and Silveira Coelho et al. [88] the antioxidant property of Quince seed and phenolic content of chia seeds were $29.88 \%$ and $641.71 \mu \mathrm{g} / \mathrm{GAE}$, respectively. 


\subsection{Antimicrobial Activity of Mucilage}

Nowadays, food safety and food quality are major challenges for all countries, it is estimated that there are around $30 \%$ of people are suffering annually from food illness disease in developed countries $[84,85]$. Many natural polymers such as proteins and carbohydrates have antibacterial and antifungal properties, which prevent or reduce the growth of microorganisms in food. Infectious microorganisms are extensively spread everywhere on the earth which causes a serious problem for society. Furthermore, natural polymers are more effective in the treatment of those diseases and also prevent several side effects that can be led by antimicrobial agents [86]. While mucilage has an antibacterial and antifungal property which can also prevent or reduce the risk of food-borne illness disease and food spoilage. Much seed-based mucilage has an antimicrobial property such as Chia seed [86], Cress seed [78], okra seed [65], and quince seed [80] Tantiwatcharothai and Prachayawarakorn [89] prepared Basil seed-based sponges hydrogel for measuring the antibacterial activity (against $S$. aureus and E. coli) in wound dressing. $\mathrm{ZnO}$ nanocomposite and borax crosslinking were also incorporated with basil seed mucilage. The result showed that there was no effect of borax in the antibacterial activity of Basil seed mucilage sponge. Whereas, $\mathrm{ZnO}$ nanocomposite loaded resulted in good antimicrobial activity against the gram-positive (Staphylococcus aureus) and gram-negative (Escherichia coli) bacteria. Furthermore, better antibacterial activity was observed against gram-positive (S. aureus) than that of gram-negative (Escherichia coli) because of the structural difference of the cell wall. Gram-negative bacteria possess a complex cell wall, while gram-positive bacteria contain a thick cell wall of peptidoglycan, therefore, it is more resistant to attack by the microbial agent. Jouki et al. [80] prepared quince seed mucilage-based film with the incorporation of thyme essential oil in different concentrations ranging from 0 to $2.0 \%$. The film was separated against eleven food associated with bacterial strains by agar disc-diffusion assay. And observed that $1 \%$ thyme essential oil containing film was more effective against all microorganisms including gram-positive and gram-negative bacteria such as Staphylococcus aureus, Listeria monocytogenes, and Shewanella putrefaciens. Mujtaba et al. [90] also prepared chia seed mucilage composite films with the incorporation of cellulose nanofibrils at various concentrations by using the solution casting method. Microorganisms such as Escherichia coli, Pseudomonas aeruginosa, Staphylococcus mutans, Salmonella typhimurium, Bacillus thuringiensis, and Staphylococcus aureus were incubated in LB agar at $37^{\circ} \mathrm{C}$ for 24 $\mathrm{h}$. the result indicated that chia seed-based cellulose nanofibrils composite film improved antimicrobial activity with the increasing of cellulose nanofibrils concentrations (3-6\%) and observed that mucilage films containing $6 \%$ cellulose nanofibrils had the highest antimicrobial capacity against all the exanimated microorganisms. The inhibition zone range of all the exanimated microorganisms was Escherichia coli $(20.17 \mathrm{~mm})$, Pseudomonas aeruginosa $(18.25 \mathrm{~mm})$, Staphylococcus mutans $(17.79 \mathrm{~mm})$, Salmonella typhimurium $(6.12 \mathrm{~mm})$, Bacillus thuringiensis $(17.19 \mathrm{~mm})$, and Staphylococcus aureus $(18.89 \mathrm{~mm})$. The antimicrobial activity of different mucilage-containing plants is represented in Table 3.

Seed and fruit mucilage show excellent activity against pathogenic gram-positive and gram-negative bacteria. The mode of action of their mechanism is proposed by several authors in various theories as shown in Figure 3, mucilage with incorporated substance exhibit antibacterial ability by binding to bacterial membranes and enters inside the cell, thus resulting in the damage of the Nucleus: DNA damage, Degradation of Protein, Cell membrane damage and Mitochondrial damage [37]. 
Table 3. Antimicrobial activity of different mucilage-containing plants.

\begin{tabular}{|c|c|c|c|c|}
\hline Mucilage & Incorporated Agent & $\begin{array}{l}\text { Gram-Positive } \\
\text { Bacteria }\end{array}$ & $\begin{array}{c}\text { Gram-Negative } \\
\text { Bacteria }\end{array}$ & References \\
\hline Basil seed mucilage & $\begin{array}{l}\text { Zinc oxide nanocomposites } \\
\text { crosslinking with borax }\end{array}$ & Staphylococcus aureus & Escherichia coli & [89] \\
\hline Quince seed mucilage & Thyme essential oil & $\begin{array}{c}\text { Bacillus cereus, Listeria } \\
\text { monocytogenes }\end{array}$ & $\begin{array}{l}\text { Salmonella typhimurium, } \\
\text { Escherichia coli, Vibrio } \\
\text { cholera, Pseudomonas } \\
\text { aeruginosa, Yersinia } \\
\text { enterocolitica }\end{array}$ & [80] \\
\hline Chia seed mucilage & $\begin{array}{l}\text { Oregano essential oils, } \\
\text { cellulose nanofibers }\end{array}$ & $\begin{array}{l}\text { Staphylococcus aureus, } \\
\text { Staphylococcus mutans, } \\
\text { Bacillus thuringiensis }\end{array}$ & $\begin{array}{c}\text { Escherichia coli, } \\
\text { Pseudomonas aeruginosa, } \\
\text { Salmonella typhmurium }\end{array}$ & {$[37,90]$} \\
\hline Okra mucilage & $\begin{array}{l}\text { Zinc oxide nanoparticles } \\
\text { and } \\
\text { carboxymethylcellulose } \\
\text { (CMC) }\end{array}$ & Staphylococcus aureus & Escherichia coli & [91] \\
\hline $\begin{array}{l}\text { Qodume shirazi seed } \\
\text { mucilage }\end{array}$ & Lavender essential oil & Staphylococcus aureus & Escherichia coli & [92] \\
\hline $\begin{array}{l}\text { Lepidium sativum seed } \\
\text { mucilage }\end{array}$ & $\begin{array}{c}\text { Heracleum lasiopetalum } \\
\text { essential oil }\end{array}$ & Staphylococcus aureus & Escherichia coli & {$[93]$} \\
\hline
\end{tabular}

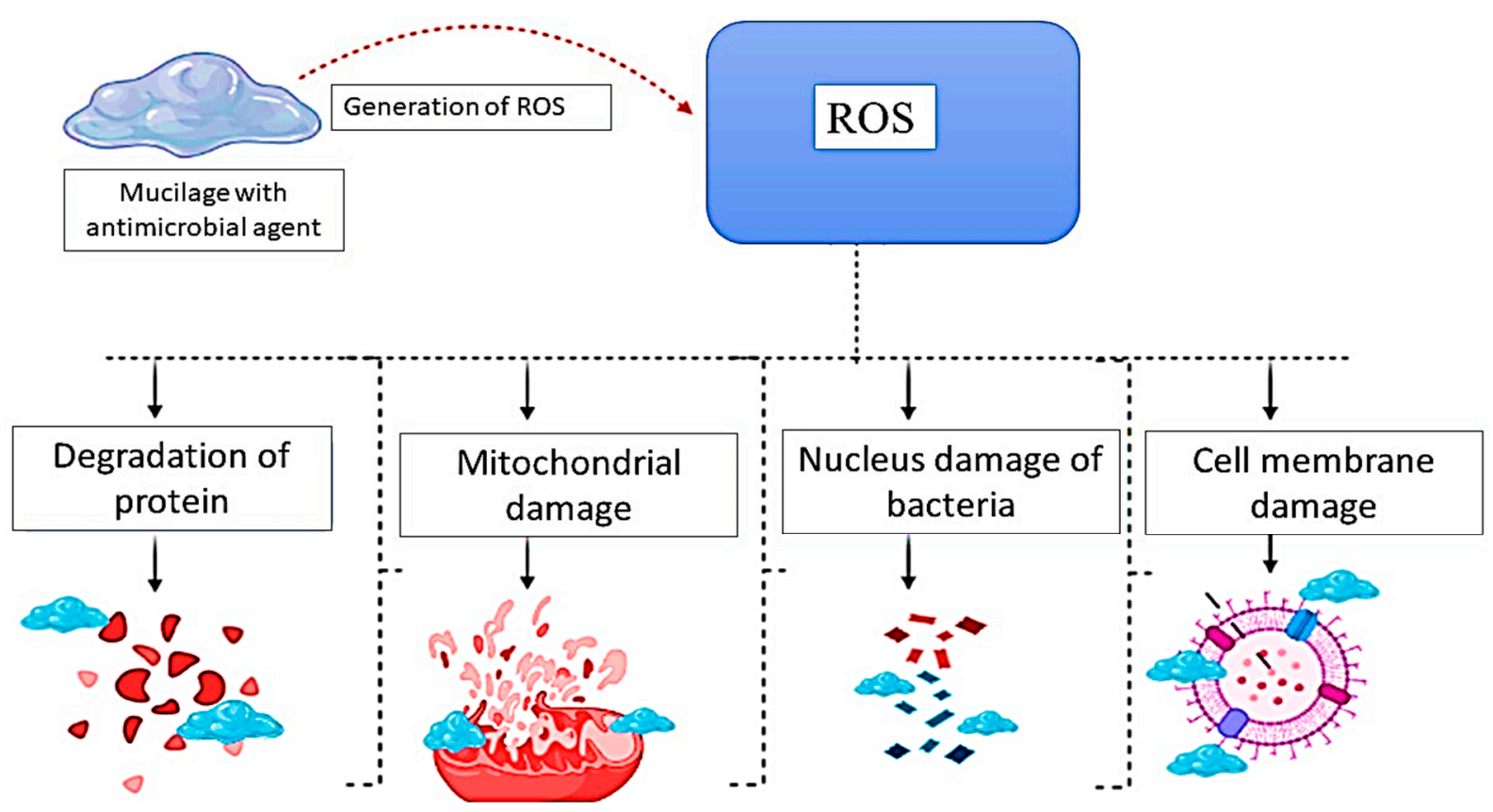

Figure 3. Possible mechanism of antimicrobial efficacy of plant-based mucilage.

The mucilage is helpful in the development of free radicals by the membrane, which leads to porosity and the death of the cell. Moreover, mucilage generates ROS (reactive oxygen species), which are free radicals that easily react with other molecules in the cell due to the presence of oxygen, which causes the damaging of proteins, RNA, and DNA [91]. Oxidative stress of ROS is a major cause of damage to the cell membrane due to lipid peroxidation. The mucilage can attach to the bacterial cell wall through several interactions in the cell membrane; therefore, the reducing the viability of the bacterial cell by inhibiting DNA replication. The bacterial cell comprises DNA bases enriched in sulfur and phosphorus, these biomaterials associate with the mucilage. Moreover, mucilage can break down the cell membrane permeability of pathogenic bacteria such as E. coli, S. 
aureus, Bacillus spp., and Pseudomonas spp., and also reduce the amount of ATP (adenosine triphosphate) by regulating the production of ATPase enzymes [92,93].

\section{Application of Mucilage}

The plant-derived additives or polymers due to their positive escape gaining importance in recent days and can be utilized as natural thickeners or emulsifiers for the human diet, therefore, act as an alternative to synthetic polymers or additives [19]. Moreover, mucilage derived from plants due to their property of elasticity can form a large number of networks molecules, therefore, can be widely used as an edible film or edible coating in food packaging applications in food industries, disintegrants in tablets, application of tablet binders, and several other applications in the pharmaceutical industry [11,94].

\subsection{Mucilage as a Coating Material}

Mucilage derived from plants can enhance the shelf life, storage capacity and also reduce the loss of moisture, therefore, extensively used as an edible coating in food packaging industries [95]. The mucilage has high tensile strength and barrier properties against different gases which reduce the firmness and weight loss of coated products [96]. Several studies have been conducted to check the effect of mucilage obtained from seeds of plants by different scientists [97]. In a study by Alizadeh Behbahani et al. [39] edible coating of Shahri Balangu seed mucilage (SBM) incorporated with cumin essential oil (CEO) on beef slices was done and a sensory study of beef slices during the storage period of 9 days was carried out. It was observed that mucilage coated beef slices reduced the loss of lipid oxidation, microbial counts (total viable count TVC), Escherichia coli, psychotropic count, yeast, and molds during the storage period. There was no adverse effect of SBM with CEO on sensory characteristics of beef and it conferred an excellent texture to the product as compared to the control sample. The different food applications of mucilage are shown in Table 4.

Table 4. Application of various plant-based Mucilage as a coating material in the food industry.

\begin{tabular}{lcc}
\hline \multicolumn{1}{c}{ Source of Mucilage } & Coating on Food & Reference \\
\hline Aloe vera & Application on tomatoes & {$[98]$} \\
Aloe vera and Basil mucilage & Application on Apricots & {$[99]$} \\
Barbery fig mucilage & Application coating on kiwi slices & {$[100]$} \\
Cress mucilage & Application on fresh beef & {$[93]$} \\
Shahri Balangu seed mucilage with & Application on beef slices & {$[39]$} \\
cumin essential oil & Application on tomato & {$[101]$} \\
Hibiscus mucilage & Application on cheddar cheese & {$[102]$} \\
Flaxseed mucilage and xanthan gum & Application on apple slices & {$[103]$} \\
Aloe vera gel & &
\end{tabular}

\subsection{Application of Mucilage as Encapsulation Agents}

Encapsulation of food ingredients, pharmaceutical ingredients, and nutraceutical ingredients is an effective technique to improve the stability of targeted compounds, apart from providing benefits on delivery characteristics [99]. The technique is used in the flavor industry to conceal undesirable taste/flavor notes such as the characteristic pungency and bitterness of polyphenols. This can be applied to a decline in the formation of rancidity in oil powders [84]. The preparation of the wall or filler material for the encapsulation of the bioactive substance is an important step because it influences the properties of the emulsion, compound preservation, and final product stabilization. several food-grade polymers have been discovered for nano and microencapsulation applications such as lipids, proteins, and carbohydrates. Furthermore, mucilage has a good ability to form a dense network after drying and their high molecular weight carbohydrate polymers make them suitable for nano and microencapsulation of food and bioactive compounds [102]. High molecular weights can aid in the retention of more key substances and increase stability. Plant-based 
mucilages are currently being investigated as wall materials for various encapsulation tests, in addition to their other applications.

\subsection{Application of Mucilage in Wound Healing}

The skin comprises the three layers of the dermis, epidermis, and hypodermis, these are known as the largest organ in the body. A wound is a mechanical or physical injury that results in breaking or opening of the skin [104]. Dressing a wound to prevent it from bacterial infection is most important to allow the wound to heal quickly. Generally, dressing absorbs the exudates from the wounded skin and prevents the pathogenic microorganisms by producing moisture at the border of the wound [89]. Plant-derived polymer due to hydrogen bond-forming groups are more extensively used for advanced and traditional wound healing and drug delivery system [105]. Mucilage-based hydrogels are non-toxic, biocompatible, biodegradable, and easily available, therefore, used for the wound healing process. These hydrogels can be naturally removed or applied with wound beds without any significant interference [106]. Likewise, Tantiwatcharothai and Prachayawarakorn [89] studied the antimicrobial effect of basil seed mucilage-based hydrogel and they observed good antimicrobial activity against pathogenic bacteria E. coli and S. aureus, isolated from the wounds. The application of mucilage in the wound healing process is explained in Figure 4 .

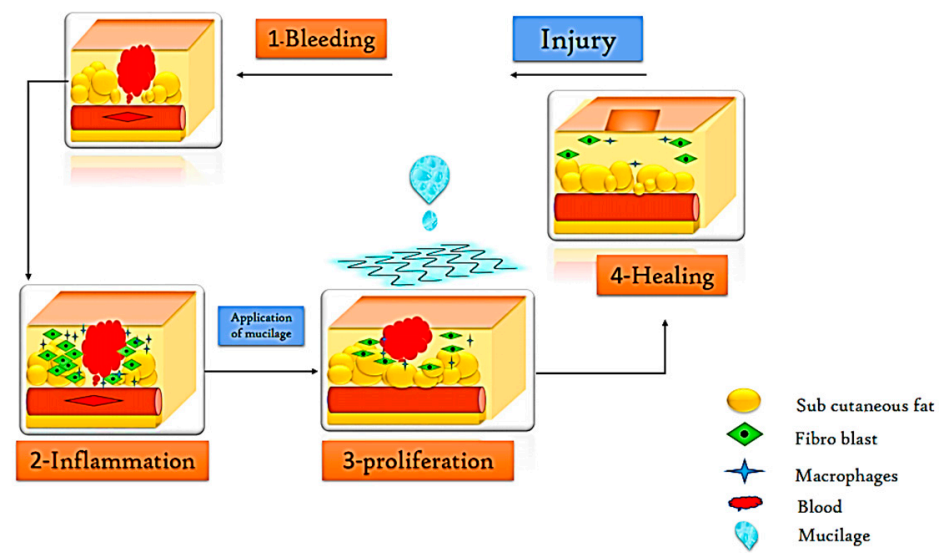

Figure 4. Application of plant-based mucilage in wound healing.

\subsection{Application of Mucilage as an Emulsifying or Suspending Agent}

Mucilage can act as a good emulsifying and suspending agent. An emulsion is a thermodynamically unstable, biphasic system, containing two non-miscible liquids that can be classified based on their droplet size into several categories, such as nano-emulsions

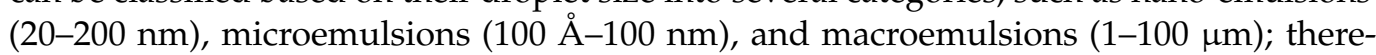
fore, they are extensively used in various industrial applications such as in the food and pharmaceutical industries [107]. Moreover, plant-derived natural emulsifying agents have effective emulsifying properties by imparting a charge to dispersed droplets, forming multimolecular sheaths around emulsion droplets by increasing the viscosity of a material [49]. The emulsifying properties of Cucumis sativus Linnaeus mucilage were also compared with commercially available tragacanth and gelatin with an additional valuation of their combined effect on the emulsion properties. They observed a high emulsifying capacity of Cucumis satious Linnaeus mucilage as a primary emulsifying agent for oil-water emulsions. Likewise, Campos et al. [108] used chia seed mucilage as a replacer emulsifier for the formation of ice cream. Chia seed mucilage maintained the quality of the product, but its sensory properties were affected due to the dark color of mucilage. Moreover, plantderived mucilage can increase the tensile strength of the hydration layer formed across the suspended solid particles by molecular interactions and hydrogen bonding. Therefore, these suspending agents perform well in the presence of moistening agents, as they do 
not reduce the interfacial surface tension. Thus, natural polysaccharides (mucilage) are commonly used as protective thickeners or colloids

\subsection{Application of Mucilage in Tablet Formations}

Mucilage is widely used for the preparation of tablets due to its high adhesive property, good swelling, and water absorption ability, therefore it can be used as a disintegrant or binding agent. Moreover, mucilage obtained from the seeds and fruits is used to sustain or modify drug release $[109,110]$. Mucilage is a binding agent that is pharmaceutical excipients used in the manufacturing of tablets to affect the coherence and aggregation of the mixed powder for the enhanced flow properties of particles and to impart physical strength to the tablet. Chaudhary et al. [111] manufactured tablets by using Grewia asiatica mucilage as a binding agent. During the in vitro dissolution study, released more than $80 \%$ of the drug within $30 \mathrm{~min}$. They observed that percentage of friability and hardness of tablets was decreased with the increasing concentration of mucilage.

\subsection{Application of Mucilage for Removal of Contaminants from Water}

Nowadays, plant-derived polymers (gums and mucilage) have attained a high demand in water purification due to their high water absorption capacities. Many components are responsible for water impurities, such as inorganic impurities (dyes), organic impurities (microorganisms), organic impurities (microorganisms), dissolved salts, heavy metals, and oils. moreover, seed or fruit mucilage is most effectively used towards such kind of water contaminators [112,113]. Furthermore, a Large concentration of contaminants in groundwater continues to be recorded as threats to the wellbeing of millions of people worldwide. Heavy metals are typically found in trace quantities in natural waters, but most are toxic even at low concentrations. Metals such as arsenic, lead, cadmium, nickel, mercury, and limited concentrations of zinc are highly dangerous for human health [114]. Heavy metals may reach the human body through food, water, air, or absorption through the skin when they come into contact with humans in agriculture, manufacturing, medicinal, industrial, or residential conditions [115]. Jones et al. [116] removed the selected heavy metal ions from the aqueous solution by using mucilage of Dicerocaryum eriocarpum (act as a biosorption). Mucilage was modified with potassium chlorides and sodium. Also Compared the potassium chlorides mucilage and sodium mucilage with non-modified deionized water mucilage. They observed that potassium chlorides mucilage increased the intensity of mucilage but did not produce new functional groups. The result of the study showed that Dicerocaryum eriocarpum mucilage has excellent binding attractions with heavy metal ions such as $\mathrm{Fe}, \mathrm{Zn}, \mathrm{Cr}$, and $\mathrm{Cd}$ in the aqueous solution. In another study, Fox et al. [117] had worked on removing heavy metal from water using cactus mucilage. Intially, they extracted mucilage from (cactus) for the removal of arsenic. and prepared two types of the extracts (i) gelling extract and (ii) non-gelling extract. Their work mainly revealed an interaction of cactus mucilage with arsenic. -CO groups (carboxyl and carbonyl groups) and $-\mathrm{OH}$ (hydroxyl) functional groups interaction with the arsenate. The outcome from their work comes is that the gelling extract shows a better average than the non-gelling extract. Mucilage extracted from Hibiscus esculentus (okra) and Malvasylvestris (mallow) and have been successful in eliminating turbidity from wastewater due to their substantial flocculation activity, however, there has been an increased (COD) chemical oxygen demand [118]. consequently, Viciafaba and Ficus-indica mucilage are environmentally friendly bio-flocculants in the treatment of COD as well as in the decoloration and turbidity from textile wastewater and have shown the capacity for more contamination removal relative to industrial flocculants such as Polyacrylamide A100PWG and EPENWATE EXP31/1, and are more likely to be environmentally safe [119].

\section{Therapeutic Importance of Mucilage}

For many decades medicinal herbs and plants are used as traditional medicine for medical treatments. It is estimated that in developing countries around $80 \%$ of the people 
are still using traditional medicines for the prevention of diseases and among them, around $25 \%$ of drugs are derived from plants [7]. Many studies revealed that plant-derived mucilage such as (fenugreek gum, yellow mustard mucilage, and flaxseed) has many health beneficial properties due to their potential of reducing or preventing the risk of type 2 diabetes [67]. Mucilage is conventionally used in the medical field via topical or oral routes for urinary, respiratory, gastrointestinal, reproductive, and musculoskeletal systems and is also used for skin disorders. Moreover, they are also extending to diabetes, cancer, immunity stimulation, and have antioxidant, and antimicrobial property. Furthermore, mucilage containing plants such as Trigonella foenum graecum has antioxidative, antimicrobial, and anti-inflammatory properties [67].

\section{Mucilage Based Nanocarriers and Their Application}

Nowadays, synthetic and non-synthetic polymers have been successfully used for the formation of a hydrogel, but plant-derived (synthetic) polymers such as proteins, polysaccharides, and polypeptides are the most preferable choice, because of their extensive use of applications. Mucilage has an excellent potential to synthesize hydrogels because of its hydrophilicity, safety, and biodegradability. Hydrogels are hydrophilic and polymeric 3D material, which retains diffusive transport of liquids as well as also retains cohesive property of solids. They have attained high demand for technologists and researchers due to their extensive range of applications. The first synthetic hydrogel was prepared in 1960. Moreover, hydrogels from the plant-derived polymers are in high demand due to the presence of functional groups such as sulfate, amide, hydroxyl, and carboxylic which increases their swelling and water holding capacity, they are also interconnected with elasticity, and microscopic pores. There are many stimuli factors such as $\mathrm{pH}$, temperature, and electric field) [120]. There are generally two methods (physical and chemical crosslinking) that are used for the formation of hydrogel along with the principles of crosslinking of a polymer chain. The chemical crosslinking method includes the creation of new covalent bonds with the hydrogel's polymer chain, while physical interaction can be also present between the polymer chain of the hydrogel. Both chemical and physical crosslinking methods can be applied for the synthesize of hydrogel from the plant-derived polymers (gum and mucilage) [121]. The formation of a nanohydrogel is explained in Figure 5. These characteristics increase the value of hydrogel as an applicant in food, pharma, and several industries [122].

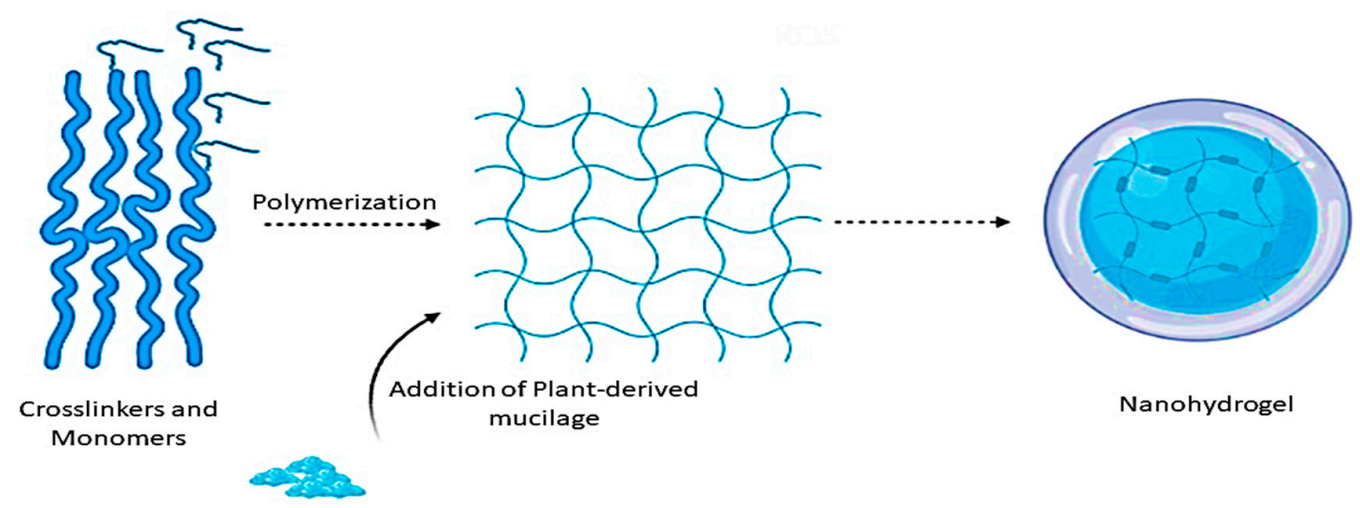

Figure 5. Synthesis of nanohydrogel using plant-based mucilage as an effective biopolymer.

The characterization of hydrogels is dependent upon the cross-linking (physical or chemical) measures during the formulation of the gel. Nanohydrogel is mostly similar to a normal hydrogel, which can be defined as a three-dimensional network of hydrophilic material (e.g., polysaccharide) with a diameter of less than $100 \mathrm{~nm}$. Nanoparticulates have many benefits when compared to micro and macrocategorization in food and several other industries. The term nanohydrogel was first introduced to describe the cross-linking and networking of poly-anions [123]. They are used in several applications such as wound 
healing, drug delivery, vaccine delivery, the enhancement of film properties, and enzyme immobilization [124,125]. Mucilage-based hydrogels containing nanocomposites form a 3D network of extreme porosity, which allows a large absorption of food or drugs in water [126]. Nanocomposites are divided into three classes: ceramic matrix nanocomposites, polymer matrix nanocomposites, and metal matrix nanocomposites. They are chosen related to macro and microcomposites due to their excellent potential properties such as mechanical, barrier, and optical characteristics. The characterization of mucilagebased nanohydrogel can be performed through different methods such as field emission scanning electron microscope (FESEM), Fourier-transform infrared spectroscopy (FTIR), X-ray diffraction (XRD), X-ray photoelectron spectroscopy (XPS), and high-resolution transmission electron microscopy (HRTEM) [127]. The mucilage-based hydrogels can act as a protector, which prevents active ingredients from degradation, oxidation, and destruction, and also has several applications in water purification, drug delivery, the food industry, tissue engineering, and agriculture. Nanomaterials improve the barrier and mechanical aspects of food packages, and other developments for intelligent and active applications in the food industry [91]. Polymers containing hydrophilic groups such as $-\mathrm{COOH},-\mathrm{OH}$, $-\mathrm{CONH}-,-\mathrm{SO}_{3} \mathrm{H}$, and $-\mathrm{CONH}_{2}$ interact with each other. Nanohydrogels are responsible for several stimuli such as temperature, electromagnetic field, $\mathrm{pH}$, ionic strength, and light. Moreover, mucilage-based nanohydrogel is mostly utilized for the preparation of the edible coatings of edible films, and it is estimated that high mucilage-containing seeds or fruits are a good source of edible gum and can be used for various applications [122]. Nanohydrogels combine the great characteristics of hydrogels, such as absorption capacity, hydrophilicity, flexibility, great water holding capacity, with the advantages of nanoparticles, allowing for obtaining better dispersion in food packaging material and decreasing the number of bioactive compounds to be applied [128]. Plant-derived mucilage-based nanohydrogels are in great demand due to their unique properties, such as biocompatibility, biodegradability, stimuli-responsive properties, and biological characteristics, making them a good material for selection in diverse applications. Furthermore, nanohydrogels have potential applications such as controlled drug delivery, biomimetic materials, and biological or chemical sensors. Nowadays, nanotechnology plays a very important role in drug delivery systems, food applications, and water purification [129]. Therefore, nanoparticles (magnetic and non-magnetic), nanofibers, nanocomposites, and nanoencapsulation are widely used as nanocarriers in various industrial applications, such as for the controlled delivery of drugs, the removal of dye, and the development of film, which are highlighted in Table 5.

Table 5. Application of seed mucilage with various nanocarriers.

\begin{tabular}{|c|c|c|c|}
\hline Seed Mucilage & Nanocarrier & Applications & References \\
\hline Basil seed mucilage & Magnetic nanoparticles $\left(\mathrm{Fe}_{3} \mathrm{O}_{4}\right)$ & $\begin{array}{l}\text { Application for the controlled delivery of } \\
\text { antibiotic (Cephalexin) }\end{array}$ & [130] \\
\hline Cress seed mucilage & Nanofibers & Application for the delivery of vitamin A & [18] \\
\hline Quince seed mucilage & Zinc oxide nanoparticles & Application for photocatalytic dye degradation & [131] \\
\hline Quince seed mucilage & Magnetic nanocomposites & $\begin{array}{l}\text { Application for removal of cationic dyes from } \\
\text { the aqueous solutions }\end{array}$ & [132] \\
\hline Basil seed mucilage & $\begin{array}{l}\text { Zinc based magnetic bio } \\
\text { nanocomposites }\end{array}$ & $\begin{array}{l}\text { Application for removal of azo anionic and } \\
\text { cationic dyes from the aqueous solutions }\end{array}$ & [133] \\
\hline Okra seed mucilage & Zinc oxide nanoparticles & Application for nanocomposites-based films & [91] \\
\hline Basil seed mucilage & $\mathrm{ZnO}$ nanocomposites & Application for wound healing & [68] \\
\hline Chia seed mucilage & Nanoencapsulation & Application as wall material & [115] \\
\hline
\end{tabular}

Moreover, Rayegan et al. [130] synthesized magnetic $\mathrm{Fe}_{3} \mathrm{O}_{4}$ nanoparticles coated with basil seed mucilage for the application of the controlled drug delivery of an antibiotic (cephalexin). The sample was characterized using XRD, FTIR, TEM, FESEM, and VSM. One-hundred and fifty magnetic nanoparticles were randomly selected for FESEM, which showed that the mean size of the nanoparticles was $6 \mathrm{~nm}$ and $12 \mathrm{~nm}$, with 0.25 and 0.28 
PDI values, respectively. Moreover, the antibacterial efficacy was evaluated by the disk diffusion method, and it was observed that there were no negative effects on the performance of drugs or on the structure by the loading of cephalexin onto the basil seed mucilage-coated magnetic nanoparticles. Moreover, it also increased the antibacterial properties of cephalexin. Consequently, Mohammadi et al. [91] prepared nanocomposite films based on okra mucilage (OM), carboxymethylcellulose (CMC), and $\mathrm{ZnO}$ nanoparticles, and evaluated their antibacterial and physicomechanical properties. In their study, they used different proportions of okra mucilage and carboxymethylcellulose $(0 / 100,30 / 70,40 / 60$, and 50/50, respectively). Colored films were observed with high levels of $\mathrm{ZnO}$ nanoparticles and okra mucilage. Moreover, due to the addition of mucilage, tensile strength was increased and elongation at the break value was decreased by the incorporation of $\mathrm{ZnO}$ nanoparticles into carboxy methylcellulose film.

\section{Synthesis of Nanoparticles with Mucilage}

Nanoparticles have attained widespread attention for the development of green, facile, and sustainable synthesis of nanoparticles. Physicochemical methods such as direct precipitation, microwave, and hydrothermal methods are widely used [132,133]. Therefore, plant-derived polymers such as gums and mucilages are effectively used for the preparation and functionalization of nanoparticles. Mucilage used for the formulation of microparticles was also exploited in nano-formulations using vitamin D loaded nanoparticles on cress seed mucilage and gelatin. The prepared particles enhanced encapsulation efficiency (around 70\%), with better in vitro release percentages of vitamin D in intestinal fluids and simulated gastroitestinal conditions [130]. Consequently, a study conducted by Pathak et al. [134] explained the achievement of using mucilage as an anionic ocular polymer for the synthesis of nanoparticles with a cationic polysaccharide polymer (chitosan). The antibacterial activity of the prepared sample was investigated against Gram-positive (Bacillus cereus and Staphylococcus aureus) and Gram-negative bacteria (Salmonella typhimurium and Escherichia coli). This type of nanoparticle can be useful in the medicinal industry for sustaining the anti-bacterial effect of antibiotics. Furthermore, the negative charge of the mucilage was additionally subjugated through the preparation of cephalexin-loaded/basil seed mucilage-coated iron oxide $\left(\mathrm{Fe}_{3} \mathrm{O}_{4}\right)$ magnetic nanoparticles. The in vitro release of antibiotic (cephalexin) from the drug-loaded coated nanoparticles at $\mathrm{pH} 7.4$ displayed biphasic form, starting with an initial quick release, then a continuous release phase. Apart from abusing the negative charge of the mucilage, phase inversion techniques and antisolvent supercritical gas using supercritical carbon dioxide as an anti-solvent were applied for the preparation of mucilage nanoparticles loaded with the cytotoxic drug paclitaxel. The nanoparticles showed high drug loading above 75, and small particle size (around 200 $\mathrm{nm}$ ) [135]. Mucilage contains flavonoids and polyphenolic contents. These compounds can efficiently bind zinc ions from an aqueous medium, and they function as stabilizing agents and natural reducers during the synthesis of nanoparticles. During the oxidation process, several carbohydrates and the counter acetate ions are also decomposed to produce high amounts of carbonate ions $(\mathrm{Ag}, \mathrm{Zn}, \mathrm{Cu}$, and $\mathrm{Co}$ ) and carbon dioxide; therefore, the binders can be removed [136-140].

\section{Market Outlook of Mucilage}

Mucilage is a gelatinous component that contains a good amount of proteins and polysaccharides, which are produced by almost all plants and a few microorganisms. It is abundantly present in agar obtained from red algae, and also in flaxseeds, fenugreek, chia seeds, marshmallow roots, psyllium, nopales, and aloe. However, a significant amount of mucilage that is used in industries is not available, and statistical consumption of mucilage is not reported. Earlier, it was primarily used for therapeutic purposes; however, it now has a variety of applications in the food, cosmetics, and health care industries [141]. The American and Asian markets have excessive utilization of mucilage in the ink, glue, and adhesive industries. The global market for cosmetics is growing, and so the use of natural 
products is as well. Therefore, the demand for mucilage for cosmetics will also increase in the upcoming years. Mucilage is useful as a binding agent in medicine, and, due to its healing properties, is used in ointments, and its cryoprotective property is increasing demands in the pharmaceutical industry [142]. The American and European mucilage market is in demand and is expected to grow positively during the forecast period. In the food industry, there is a growing demand for processed foods that contain mucilage as a thickening, gel-forming, and emulsifying agent. It is also used as a stabilizer in the milk industry, such as in ice cream, yogurt, and, flavored milk. Moreover, mucilage-derived hydrocolloids have been used in the food industry to provide textural functionality, such as in fruit fillings, water binding in meat products, dairy-based beverages, desserts, and jams [143]. Mucilages contain different kinds of antioxidants that slow the aging process, and thus can also be used in cosmetics products. Furthermore, mucilage is used for its health advantages, including bolstering the immune system, soothing the gastrointestinal tract, the ability to lower low-density lipids, and lowering blood pressure, which makes it applicable in pharmaceuticals and medicine. In the forecast period, there will be significant market growth in the pharmaceutical, health care, and medicine markets.

Nowadays, intensive research is underway on plant-derived mucilage-based edible coatings and films to enhance the shelf life of fruits, vegetables, meats, and fish products. Similarly, mucilage is being used to develop nanofibers, which creates a large market for the textile industry in fabrication. The hydrophilic nature of mucus can act as a barrier to water penetration, delaying water loss and prolonging firmness [144]. This property makes it a promising component for cosmetic industry applications. Therefore, it is to be expected that, in the coming years, the slime market will include a wide range of applications and new market development.

\section{Conclusions, Future Research Perspectives, and Challenges}

In recent years, plant-derived polymeric carbohydrates have acquired high demand from food industries due to their diverse applications, such as as film coatings, emulsifiers, binders, and gelling agents. Among all carbohydrate polymers, mucilage has been abundantly used in the field of modern science due to its diverse applications. Plant-derived mucilage can be obtained from the special mucilage cells of different plant parts. Moreover, mucilage is mainly composed of complex carbohydrate polymers with highly branched structures that consist of L-arabinose, D-xylose, D-galactose, L-rhamnose, and galacturonic acid. They also contain glycoproteins and different bioactive components such as tannins, alkaloids, and steroids. Due to these properties, plant-derived mucilages can be used as an active functional ingredient, emulsifier, surfactant, stabilizer, encapsulating material, or cross-linker; therefore, they could be used for the fabrication of different types of nanocarrier. Moreover, researchers revealed broad-spectrum applications of biopolymer fabricated nanocarriers, especially nanohydrogels and metal nanoparticles, in the fields of medical and food sciences. Mucilage is a plant-derived polymer, their availability varies based on seasonal and environmental conditions. Apart from agronomical variations, these variations may affect the quality and production of mucilages; however, the extraction and purification processes are very complicated. Inadequate removal of mucilage, physical damage to the seed, and morphological features of the plant parts containing mucilage may all affect mucilage yield and consistency, posing a serious challenge to associated costs and the potential for mass production. The toxicity of mucilages is determined by their chemical composition and mode of action in food systems. As a result, it is important to determine the toxicity level of mucilages, particularly the presence of heavy metals in different plant sources. The toxic effects of mucilages can be determined using the fixed-dose procedure, which is recommended by guideline number 425 of the Organization for Economic Cooperation and Development (OECD). Mucilage contains around 10\% moisture content, therefore the risk of microbial contamination during any stage of their processing may be high. This is due to the presence of biological substances that promote the growth and production of microorganisms in favorable conditions. Furthermore, the 
storage period is also a key factor in the contamination of mucilage. Studies have reported that variation in storage conditions leads to changes in the quality of mucilage. This often requires proper control of the different handling methods used at various stages of the supply chain. Moreover, modifications can also be made to address the disadvantages of uncontrolled biodegradability, shear instability, thermal decomposition, $\mathrm{pH}$ dependence, thickening, and uncontrolled hydration.

Author Contributions: Conceptualization, P.C., A.N. and M.M.T.; Resources, A.B., R.K. and S.B.D.; Writing-original draft preparation, M.M.T., A.B., R.K. and S.B.D.; writing—review and editing, A.N.; visualization, A.B. and M.W.-J.; supervision, A.N. and P.C. All authors have read and agreed to the published version of the manuscript.

Funding: This research received no external funding.

Institutional Review Board Statement: Not applicable.

Informed Consent Statement: Not applicable.

Data Availability Statement: Data sharing is not applicable to this article.

Conflicts of Interest: The authors declare no conflict of interest.

\section{References}

1. Ma, F.; Wang, R.; Li, X.; Kang, W.; Bell, A.E.; Zhao, D.; Liu, X.; Chen, W. Physical properties of mucilage polysaccharides from dioscorea Opposita Thunb. Food Chem. 2020, 311. [CrossRef]

2. Singh, R.; Barreca, D.N. Analysis of gums and mucilages. In Recent Advances in Natural Products Analysis; Silva, A.S., Nabavi, S.F., Saeedi, M., Nabavi, S.M., Eds.; Elsevier: Amsterdam, The Netherlands, 2020; pp. 663-676. [CrossRef]

3. Freitas, T.K.F.S.; Oliveira, V.M.; de Souza, M.T.F.; Geraldino, H.C.L.; Almeida, V.C.; Fávaro, S.L.; Garcia, J.C. Optimization of coagulation-flocculation process for treatment of industrial textile wastewater using okra (A. esculentus) mucilage as natural coagulant. Ind. Crop. Prod. 2015, 76, 538-544. [CrossRef]

4. Gasperini, L.; Mano, J.F.; Reis, R.L. Natural polymers for the microencapsulation of cells. J. R. Soc. Interface 2014, 11. [CrossRef]

5. Chawla, P.; Kumar, N.; Bains, A.; Dhull, S.B.; Kumar, M.; Kaushik, R.; Punia, S. Gum arabic capped copper nanoparticles: Synthesis, characterization, and applications. Int. J. Biol. Macromol. 2020, 146, 232-242. [CrossRef] [PubMed]

6. Archana, G.; Sabina, K.; Babuskin, S.; Radhakrishnan, K.; Fayidh, M.A.; Azhagu Saravana Babu, P.; Sivarajan, M.; Sukumar, M. Preparation and characterization of mucilage polysaccharide for biomedical applications. Carbohydr. Polym. 2013, 98, 89-94. [CrossRef]

7. Ameri, A.; Heydarirad, G.; Jafari, J.M.; Ghobadi, A.; Rezaeizadeh, H.; Choopani, R. Medicinal plants contain mucilage used in traditional Persian medicine (TPM). Pharm. Biol. 2015, 53, 615-623. [CrossRef]

8. Fernandes, S.S.; de las Mercedes Salas-Mellado, M. Addition of chia seed mucilage for reduction of fat content in bread and cakes. Food Chem. 2017, 227, 237-244. [CrossRef]

9. Beikzadeh, S.; Khezerlou, A.; Jafari, S.M.; Pilevar, Z.; Mortazavian, A.M. Seed Mucilages as the functional ingredients for biodegradable films and edible coatings in the food industry. Adv. Colloid Interface Sci. 2020, 280, 102164. [CrossRef]

10. Gebresamuel, N.; Gebre-Mariam, T. Comparative physico-chemical characterization of the mucilages of two cactus pears (Opuntia Spp.) obtained from Mekelle, Northern Ethiopia. J. Biomater. Nanobiotechnol. 2012, 3, 79-86. [CrossRef]

11. Prajapati, V.D.; Jani, G.K.; Moradiya, N.G.; Randeria, N.P. Pharmaceutical applications of various natural gums, mucilages and their modified forms. Carbohydr. Polym. 2013, 92, 1685-1699. [CrossRef] [PubMed]

12. Petera, B.; Delattre, C.; Pierre, G.; Wadouachi, A.; Elboutachfaiti, R.; Engel, E.; Poughon, L.; Michaud, P.; Fenoradosoa, T.A. Characterization of arabinogalactan-rich mucilage from cereus triangularis cladodes. Carbohydr. Polym. 2015, 127, 372-380. [CrossRef]

13. Alpizar-Reyes, E.; Carrillo-Navas, H.; Gallardo-Rivera, R.; Varela-Guerrero, V.; Alvarez-Ramirez, J.; Pérez-Alonso, C. Functional properties and physicochemical characteristics of tamarind (Tamarindus indica L.) seed mucilage powder as a novel hydrocolloid. J. Food Eng. 2017, 209, 68-75. [CrossRef]

14. Hosseini, S.M.; Hemmati, K.; Ghaemy, M. Synthesis of nanohydrogels based on tragacanth gum biopolymer and investigation of swelling and drug delivery. Int. J. Biol. Macromol. 2016, 82, 806-815. [CrossRef]

15. Sharma, G.; Kumar, A.; Devi, K.; Sharma, S.; Naushad, M.; Ghfar, A.A.; Ahamad, T.; Stadler, F.J. Guar Gum-Crosslinked-Soya lecithin nanohydrogel sheets as effective adsorbent for the removal of thiophanate methyl fungicide. Int. J. Biol. Macromol. 2018, 114, 295-305. [CrossRef] [PubMed]

16. Oh, J.K.; Lee, D.I.; Park, J.M. Biopolymer-based microgels/nanogels for drug delivery applications. Prog. Polym. Sci. 2009, 34, 1261-1282. [CrossRef]

17. Suner, S.S.; Sahiner, M.; Sengel, S.B.; Rees, D.J.; Reed, W.F.; Sahiner, N. Responsive biopolymer-based microgels/nanogels for drug delivery applications. Stimuli Responsive Polym. Nanocarriers Drug Deliv. Appl. 2018, 1, 453-500. [CrossRef] 
18. Mukherjee, T.; Lerma-Reyes, R.; Thompson, K.A.; Schrick, K. Making glue from seeds and gums: Working with plant-based polymers to introduce students to plant biochemistry. Biochem. Mol. Biol. Educ. 2019, 47, 468-475. [CrossRef]

19. Viudes, S.; Burlat, V.; Dunand, C. Seed mucilage evolution: Diverse molecular mechanisms generate versatile ecological functions for particular environments. Plant Cell Environ. 2020, 43, 2857-2870. [CrossRef]

20. Ferreira, B.; Montesinos, D.; Sales, F. Mucilage in Portuguese Lamiaceae. Bot. Lett. 2020, 167, 430-438. [CrossRef]

21. Cuomo, F.; Iacovino, S.; Cinelli, G.; Messia, M.C.; Marconi, E.; Lopez, F. Effect of additives on chia mucilage suspensions: A rheological approach. Food Hydrocoll. 2020, 109, 106118. [CrossRef]

22. Zhang, K.; Zhang, Y.; Ji, Y.; Walck, J.L.; Tao, J. Seed Biology of Lepidium apetalum (Brassicaceae), with particular reference to dormancy and mucilage development. Plants 2020, 9, 333. [CrossRef] [PubMed]

23. Yang, X.; Baskin, J.M.; Baskin, C.C.; Huang, Z. More than just a coating: Ecological importance, taxonomic occurrence and phylogenetic relationships of seed coat mucilage. Perspect. Plant Ecol. Evol. Syst. 2012, 14, 434-442. [CrossRef]

24. Cai, M.; Wang, N.; Xing, C.; Wang, F.; Wu, K.; Du, X. Immobilization of aluminum with mucilage secreted by root cap and root border cells is related to aluminum resistance in Glycine max L. Environ. Sci. Pollut. Res. 2013, 20, 8924-8933. [CrossRef] [PubMed]

25. Hawes, M.C.; Curlango-Rivera, G.; Xiong, Z.; Kessler, J.O. Roles of root border cells in plant defense and regulation of rhizosphere microbial populations by extracellular DNA 'trappin'. Plant Soil 2012, 355, 1-16. [CrossRef]

26. Rashid, F.; Ahmed, Z.; Hussain, S.; Huang, J.Y.; Ahmad, A. Linum usitatissimum L. seeds: Flax gum extraction, physicochemical and functional characterization. Carbohydr. Polym. 2019, 215, 29-38. [CrossRef]

27. Coorey, R.; Tjoe, A.; Jayasena, V. Gelling properties of chia seed and flour. J. Food Sci. 2014, 79, E859-E866. [CrossRef]

28. Nayak, A.K.; Pal, D.; Pradhan, J.; Hasnain, M.S. Fenugreek seed mucilage-alginate mucoadhesive beads of metformin HCl: Design, optimization and evaluation. Int. J. Biol. Macromol. 2013, 54, 144-154. [CrossRef]

29. Nayak, A.K.; Pal, D.; Pany, D.R.; Mohanty, B. Evaluation of Spinacia oleracea L. leaves mucilage as an innovative suspending agent. J. Adv. Pharm. Technol. Res. 2010, 1, 338-341. [CrossRef]

30. Tavares, L.S.; Junqueira, L.A.; de Oliveira Guimarães, Í.C.; de Resende, J.V. Cold extraction method of chia seed mucilage (Salvia hispanica L.): Effect on yield and rheological behavior. J. Food Sci. Technol. 2018, 55, 457-466. [CrossRef]

31. Jindal, M.; Kumar, V.; Rana, V.; Tiwary, A.K. Exploring potential new gum source aegle marmelos for food and pharmaceuticals: Physical, chemical and functional performance. Ind. Crop. Prod. 2013, 45, 312-318. [CrossRef]

32. Hung, P.Y.; Lai, L.S. Structural characterization and rheological properties of the water extracted mucilage of basella alba and the starch/aqueous mucilage blends. Food Hydrocoll. 2019, 93, 413-421. [CrossRef]

33. Souza, G.; Siqueira dos Santos, S.; Bergamasco, R.; Antigo, J.; Madrona, G.S. Antioxidant activity, extraction and application of psyllium mucilage in chocolate drink. Nutr. Food Sci. 2020, 50, 1175-1185. [CrossRef]

34. Andrade, L.A.; de Oliveira Silva, D.A.; Nunes, C.A.; Pereira, J. Experimental techniques for the extraction of taro mucilage with enhanced emulsifier properties using chemical characterization. Food Chem. 2020, 327, 127095. [CrossRef] [PubMed]

35. Kamel, R.; Afifi, S.M.; Kassem, I.A.A.; Elkasabgy, N.A.; Farag, M.A. Arabinoxylan and rhamnogalacturonan mucilage: Outgoing and potential trends of pharmaceutical, environmental, and medicinal merits. Int. J. Biol. Macromol. 2020, 165, $2550-2564$. [CrossRef]

36. Andrade, L.A.; Nunes, C.A.; Pereira, J. Relationship between the chemical components of taro rhizome mucilage and its emulsifying property. Food Chem. 2015, 178, 331-338. [CrossRef] [PubMed]

37. Elboutachfaiti, R.; Delattre, C.; Quéro, A.; Roulard, R.; Duchêne, J.; Mesnard, F.; Petit, E. Fractionation and structural characterization of six purified rhamnogalacturonans type i from flaxseed mucilage. Food Hydrocoll. 2017, 62, 273-279. [CrossRef]

38. Luo, M.; Cao, Y.; Wang, W.; Chen, X.; Cai, J.; Wang, L.; Xiao, J. Sustained-release antimicrobial gelatin film: Effect of chia mucilage on physicochemical and antimicrobial properties. Food Hydrocoll. 2019, 87, 783-791. [CrossRef]

39. Behbahani, B.A.; Noshad, M.; Jooyandeh, H. Improving oxidative and microbial stability of beef using Shahri Balangu seed mucilage loaded with Cumin essential oil as a bioactive edible coating. Biocatal. Agric. Biotechnol. 2020, 24, 101563. [CrossRef]

40. Pereira, G.A.; Silva, E.K.; Peixoto Araujo, N.M.; Arruda, H.S.; Meireles, M.A.A.; Pastore, G.M. Mutamba seed mucilage as a novel emulsifier: Stabilization mechanisms, kinetic stability and volatile compounds retention. Food Hydrocoll. 2019, $97,105190$. [CrossRef]

41. Soukoulis, C.; Gaiani, C.; Hoffmann, L. Plant seed mucilage as emerging biopolymer in food industry applications. Curr. Opin. Food Sci. 2018, 22, 28-42. [CrossRef]

42. Vardhanabhuti, B.; Ikeda, S. Isolation and characterization of hydrocolloids from monoi (Cissampelos pareira) leaves. Food Hydrocoll. 2006, 20, 885-891. [CrossRef]

43. Naji-Tabasi, S.; Razavi, S.M.A. Functional properties and applications of basil seed gum: An overview. Food Hydrocoll. 2017, 73, 313-325. [CrossRef]

44. Hesarinejad, M.A.; Sami Jokandan, M.; Mohammadifar, M.A.; Koocheki, A.; Razavi, S.M.A.; Ale, M.T.; Attar, F.R. The effects of concentration and heating-cooling rate on rheological properties of plantago lanceolata seed mucilage. Int. J. Biol. Macromol. 2018, 115, 1260-1266. [CrossRef]

45. Hosseini-Parvar, S.H.; Matia-Merino, L.; Goh, K.K.T.; Razavi, S.M.A.; Mortazavi, S.A. Steady shear flow behavior of gum extracted from Ocimum basilicum L. seed: Effect of concentration and temperature. J. Food Eng. 2010, 101, 236-243. [CrossRef]

46. Timilsena, Y.P.; Adhikari, R.; Barrow, C.J.; Adhikari, B. Physicochemical and functional properties of protein isolate produced from Australian chia seeds. Food Chem. 2016, 212, 648-656. [CrossRef] [PubMed] 
47. Mirhosseini, H.; Amid, B.T. A Review study on chemical composition and molecular structure of newly plant gum exudates and seed gums. Food Res. Int. 2012, 46, 387-398. [CrossRef]

48. Deore, U.V.; Mahajan, H.S. Isolation and characterization of natural polysaccharide from cassia obtustifolia seed mucilage as film forming material for drug delivery. Int. J. Biol. Macromol. 2018, 115, 1071-1078. [CrossRef] [PubMed]

49. Dehghani, S.; Noshad, M.; Rastegarzadeh, S.; Hojjati, M.; Fazlara, A. Electrospun chia seed mucilage/pva encapsulated with green cardamonmum essential oils: Antioxidant and antibacterial property. Int. J. Biol. Macromol. 2020, 161, 1-9. [CrossRef]

50. Devi, R.; Bhatia, M. Thiol Functionalization of Flaxseed Mucilage: Preparation, characterization and evaluation as mucoadhesive polymer. Int. J. Biol. Macromol. 2019, 126, 101-106. [CrossRef] [PubMed]

51. Thessrimuang, N.; Prachayawarakorn, J. Development, modification and characterization of new biodegradable film from basil seed (Ocimum basilicum L.) mucilage. J. Sci. Food Agric. 2019, 99, 5508-5515. [CrossRef]

52. Fahami, A.; Fathi, M. Development of cress seed mucilage/PVA nanofibers as a novel carrier for vitamin a delivery. Food Hydrocoll. 2018, 81, 31-38. [CrossRef]

53. Kurd, F.; Fathi, M.; Shekarchizadeh, H. Basil seed mucilage as a new source for electrospinning: Production and physicochemical characterization. Int. J. Biol. Macromol. 2017, 95, 689-695. [CrossRef]

54. Naji-Tabasi, S.; Razavi, S.M.A.; Mohebbi, M.; Malaekeh-Nikouei, B. New studies on basil (Ocimum bacilicum L.) seed gum: Part i-Fractionation, physicochemical and surface activity characterization. Food Hydrocoll. 2016, 52, 350-358. [CrossRef]

55. Pratik, P.; Shadique, A. Antimicrobial examination of mucilage obtained from fruits of tilkor [Mamoradica monadelpha]: A potential medicinal plant. J. Biol. Chem. Chron. 2020, 6, 5-9. [CrossRef]

56. Punia, S.; Dhull, S.B. Chia seed (Salvia hispanica L.) mucilage (a heteropolysaccharide): Functional, thermal, rheological behaviour and its utilization. Int. J. Biol. Macromol. 2019, 140, 1084-1090. [CrossRef] [PubMed]

57. Capitani, M.I.; Ixtaina, V.Y.; Nolasco, S.M.; Tomás, M.C. Microstructure, chemical composition and mucilage exudation of chia (Salvia hispanica L.) nutlets from Argentina. J. Sci. Food Agric. 2013, 93, 3856-3862. [CrossRef]

58. Abbastabar, B.; Azizi, M.H.; Adnani, A.; Abbasi, S. Determining and modeling rheological characteristics of quince seed gum. Food Hydrocoll. 2015, 43, 259-264. [CrossRef]

59. Keshani-Dokht, S.; Emam-Djomeh, Z.; Yarmand, M.S.; Fathi, M. Extraction, chemical composition, rheological behavior, antioxidant activity and functional properties of Cordia myxa mucilage. Int. J. Biol. Macromol. 2018, 118, 485-493. [CrossRef] [PubMed]

60. Hadad, S.; Goli, S.A.H. Fabrication and characterization of electrospun nanofibers using flaxseed (Linum usitatissimum) Mucilage. Int. J. Biol. Macromol. 2018, 114, 408-414. [CrossRef] [PubMed]

61. Singh, S.; Bothara, S.B. Manilkara zapota (Linn.) seeds: A potential source of natural gum. ISRN Pharm. 2014, $2014,647174$. [CrossRef] [PubMed]

62. de Alvarenga Pinto Cotrim, M.; Mottin, A.C.; Ayres, E. Preparation and characterization of Okra Mucilage (Abelmoschus esculentus) edible films. Macromol. Symp. 2016, 367, 90-100. [CrossRef]

63. Pawar, H.A.; Lalitha, K.G. Isolation, purification and characterization of galactomannans as an excipient from Senna tora seeds. Int. J. Biol. Macromol. 2014, 65, 167-175. [CrossRef]

64. Viebke, C.; Al-Assaf, S.; Phillips, G.O. Food hydrocolloids and health claims. Bioact. Carbohydr. Diet. Fibre 2014, 4, 101-114. [CrossRef]

65. Kang, S.; Wang, H.; Xia, L.; Chen, M.; Li, L.; Cheng, J.; Li, X.; Jiang, S. Colorimetric film based on polyvinyl alcohol/okra mucilage polysaccharide incorporated with rose anthocyanins for shrimp freshness monitoring. Carbohydr. Polym. 2020, $229,115402$. [CrossRef]

66. Gemede, H.F.; Haki, G.D.; Beyene, F.; Rakshit, S.K.; Woldegiorgis, A.Z. Indigenous Ethiopian Okra (Abelmoschus Esculentus) Mucilage: A Novel Ingredient with Functional and Antioxidant Properties. Food Sci. Nutr. 2018, 6, 563-571. [CrossRef] [PubMed]

67. Ubeyitogullari, A.; Ciftci, O.N. Fabrication of bioaerogels from camelina seed mucilage for food applications. Food Hydrocoll. 2020, 102, 105597. [CrossRef]

68. Kaur, M.; Kaur, R.; Punia, S. Characterization of mucilages extracted from different flaxseed (Linum usitatissiumum L.) cultivars: A heteropolysaccharide with desirable functional and rheological properties. Int. J. Biol. Macromol. 2018, 117, 919-927. [CrossRef]

69. Lan, Y.; Ohm, J.B.; Chen, B.; Rao, J. Physicochemical properties and aroma profiles of flaxseed proteins extracted from whole flaxseed and flaxseed meal. Food Hydrocoll. 2020, 104, 105731. [CrossRef]

70. Hassan, L.K.; Haggag, H.F.; ElKalyoubi, M.H.; Abd EL-Aziz, M.; El-Sayed, M.M.; Sayed, A.F. Physico-chemical properties of yoghurt containing cress seed mucilage or guar gum. Ann. Agric. Sci. 2015, 60, 21-28. [CrossRef]

71. Dhull, S.B.; Sandhu, K.S.; Punia, S.; Kaur, M.; Chawla, P.; Malik, A. Functional, thermal and rheological behavior of fenugreek (Trigonella foenum-graecum L.) gums from different cultivars: A comparative study. Int. J. Biol. Macromol. 2020, 159, $406-414$. [CrossRef] [PubMed]

72. Galla, N.R.; Dubasi, G.R. Chemical and functional characterization of Gum Karaya (Sterculia urens L.) seed meal. Food Hydrocoll. 2010, 24, 479-485. [CrossRef]

73. Felisberto, M.H.F.; Wahanik, A.L.; Gomes-Ruffi, C.R.; Clerici, M.T.P.S.; Chang, Y.K.; Steel, C.J. Use of chia (Salvia hispanica L.) mucilage gel to reduce fat in pound cakes. LWT Food Sci. Technol. 2015, 63, 1049-1055. [CrossRef]

74. Monrroy, M.; García, E.; Ríos, K.; García, J.R. Extraction and physicochemical characterization of mucilage from Opuntia cochenillifera (L.) Miller. J. Chem. 2017, 2017. [CrossRef] 
75. Kalegowda, P.; Chauhan, A.S.; Nanjaraj Urs, S.M. Opuntia dillenii (Ker-Gawl) haw cladode mucilage: Physico-chemical, rheological and functional behavior. Carbohydr. Polym. 2017, 157, 1057-1064. [CrossRef] [PubMed]

76. Hayati, I.N.; Ching, C.W.; Rozaini, M.Z.H. Flow properties of o/w emulsions as affected by xanthan gum, guar gum and carboxymethyl cellulose interactions studied by a mixture regression modelling. Food Hydrocoll. 2016, 53, 199-208. [CrossRef]

77. Quinzio, C.; Ayunta, C.; López de Mishima, B.; Iturriaga, L. Stability and rheology properties of oil-in-water emulsions prepared with mucilage extracted from opuntia Ficus-indica (L). Miller. Food Hydrocoll. 2018, 84, 154-165. [CrossRef]

78. Sangeethapriya, M.; Siddhuraju, P. Health related functional characteristics and antioxidant potential of mucilage (dietary fiber) from Zizyphus mauritiana fruits. Food Sci. Hum. Wellness 2014, 3, 79-88. [CrossRef]

79. Behrouzian, F.; Razavi, S.M.A.; Phillips, G.O. Cress seed (Lepidium sativum) mucilage, an overview. Bioact. Carbohydr. Diet. Fibre 2014, 3, 17-28. [CrossRef]

80. Jouki, M.; Mortazavi, S.A.; Yazdi, F.T.; Koocheki, A. Characterization of antioxidant-antibacterial quince seed mucilage films containing thyme essential oil. Carbohydr. Polym. 2014, 99, 537-546. [CrossRef]

81. Mahfoudhi, N.; Sessa, M.; Chouaibi, M.; Ferrari, G.; Donsì, F.; Hamdi, S. assessment of emulsifying ability of almond gum in comparison with gum arabic using response surface methodology. Food Hydrocoll. 2014, 37, 49-59. [CrossRef]

82. Alizadeh Behbahani, B.; Tabatabaei Yazdi, F.; Shahidi, F.; Hesarinejad, M.A.; Mortazavi, S.A.; Mohebbi, M. Plantago major seed mucilage: Optimization of extraction and some physicochemical and rheological aspects. Carbohydr. Polym. 2017, 155, 68-77. [CrossRef]

83. Safaei-Ghomi, J.; Ebrahimabadi, A.H.; Djafari-Bidgoli, Z.; Batooli, H. GC/MS analysis and in vitro antioxidant activity of essential oil and methanol extracts of Thymus caramanicus Jalas and its main constituent carvacrol. Food Chem. 2009, 115, 1524-1528. [CrossRef]

84. Roche, A.; Ross, E.; Walsh, N.; O’Donnell, K.; Williams, A.; Klapp, M.; Fullard, N.; Edelstein, S. Representative literature on the phytonutrients category: Phenolic acids. Crit. Rev. Food Sci. Nutr. 2017, 57, 1089-1096. [CrossRef]

85. Wang, J.; Hu, S.; Nie, S.; Yu, Q.; Xie, M. Reviews on mechanisms of in vitro antioxidant activity of polysaccharides. Oxidative Med. Cell. Longev. 2016, 64,1-13. [CrossRef]

86. Zhao, Q.; Dong, B.; Chen, J.; Zhao, B.; Wang, X.; Wang, L.; Zha, S.; Wang, Y.; Zhang, J.; Wang, Y. Effect of drying methods on physicochemical properties and antioxidant activities of wolfberry (Lycium barbarum) polysaccharide. Carbohydr. Polym. 2015, 127, 176-181. [CrossRef]

87. Liguori, G.; Gentile, C.; Gaglio, R.; Perrone, A.; Guarcello, R.; Francesca, N.; Fretto, S.; Inglese, P.; Settanni, L. Effect of addition of Opuntia ficus-indica mucilage on the biological leavening, physical, nutritional, antioxidant and sensory aspects of bread. $J$. Biosci. Bioeng. 2020, 129, 184-191. [CrossRef] [PubMed]

88. Silveira Coelho, M.; de las Mercedes Salas-Mellado, M. Chemical characterization of chia (Salvia Hispanica L.) for use in food products. J. Food Nutr. Res. 2014, 2, 263-269. [CrossRef]

89. Tantiwatcharothai, S.; Prachayawarakorn, J. Property improvement of antibacterial wound dressing from basil seed (O. basilicum L.) mucilage-ZnO nanocomposite by borax crosslinking. Carbohydr. Polym. 2020, 227, 115360-115367. [CrossRef] [PubMed]

90. Mujtaba, M.; Akyuz, L.; Koc, B.; Kaya, M.; Ilk, S.; Cansaran-Duman, D.; Martinez, A.S.; Cakmak, Y.S.; Labidi, J.; Boufi, S. Novel, multifunctional mucilage composite films incorporated with cellulose nanofibers. Food Hydrocoll. 2019, 89, 20-28. [CrossRef]

91. Mohammadi, H.; Kamkar, A.; Misaghi, A. Nanocomposite films based on cmc, okra mucilage and ZnO nanoparticles: Physico mechanical and antibacterial properties. Carbohydr. Polym. 2018, 181, 351-357. [CrossRef] [PubMed]

92. Heydari, S.; Jooyandeh, H.; Alizadeh Behbahani, B.; Noshad, M. The Impact of Qodume Shirazi seed mucilage-based edible coating containing lavender essential oil on the quality enhancement and shelf life improvement of fresh ostrich meat: An experimental and modeling study. Food Sci. Nutr. 2020, 8, 6497-6512. [CrossRef] [PubMed]

93. Barzegar, H.; Alizadeh Behbahani, B.; Mehrnia, M.A. Quality retention and shelf life extension of fresh beef using Lepidium sativum seed mucilage-based edible coating containing Heracleum lasiopetalum essential oil: An experimental and modeling study. Food Sci. Biotechnol. 2020, 29, 717-728. [CrossRef] [PubMed]

94. Gheribi, R.; Puchot, L.; Verge, P.; Jaoued-Grayaa, N.; Mezni, M.; Habibi, Y.; Khwaldia, K. Development of plasticized edible films from Opuntia ficus-indica mucilage: A comparative study of various polyol plasticizers. Carbohydr. Polym. 2018, 190, $204-211$. [CrossRef]

95. Mir, S.A.; Dar, B.N.; Wani, A.A.; Shah, M.A. Effect of plant extracts on the techno-functional properties of biodegradable packaging films. Trends Food Sci. Technol. 2018, 80, 141-154. [CrossRef]

96. Espino-Díaz, M.; De Jesús Ornelas-Paz, J.; Martínez-Téllez, M.A.; Santillán, C.; Barbosa-Cánovas, G.V.; Zamudio-Flores, P.B.; Olivas, G.I. Development and characterization of edible films based on mucilage of Opuntia ficus-indica (L.). J. Food Sci. 2010, 75, E347-E352. [CrossRef] [PubMed]

97. Kozlu, A.; Elmac1, Y. Quince seed mucilage as edible coating for mandarin fruit; determination of the quality characteristics during storage. J. Food Process. Preserv. 2020, 44, e14854. [CrossRef]

98. Chrysargyris, A.; Nikou, A.; Tzortzakis, N. Effectiveness of Aloe vera gel coating for maintaining tomato fruit quality. N. Z. J. Crop Hortic. Sci. 2016, 44, 203-217. [CrossRef]

99. Nourozi, F.; Sayyari, M. Enrichment of Aloe vera gel with basil seed mucilage preserve bioactive compounds and postharvest quality of apricot fruits. Sci. Hortic. 2020, 262, 109041. [CrossRef] 
100. Allegra, A.; Inglese, P.; Sortino, G.; Settanni, L.; Todaro, A.; Liguori, G. The influence of Opuntia ficus-indica mucilage edible coating on the quality of 'Hayward' kiwifruit slices. Postharvest Biol. Technol. 2016, 120, 45-51. [CrossRef]

101. Vignesh, R.M.; Nair, B.R. Improvement of shelf life quality of tomatoes using a novel edible coating formulation. Plant Sci. Today 2019, 2, 84-90. [CrossRef]

102. Soleimani-Rambod, A.; Zomorodi, S.; Naghizadeh Raeisi, S.; Khosrowshahi Asl, A.; Shahidi, S.-A. The Effect of Xanthan Gum and Flaxseed Mucilage as Edible Coatings in Cheddar Cheese during Ripening. Coatings 2018, 8, 80. [CrossRef]

103. Song, H.Y.; Jo, W.S.; Song, N.B.; Min, S.C.; Song, K.B. Quality change of apple slices coated with Aloe vera gel during storage. J. Food Sci. 2013, 78, 817-822. [CrossRef]

104. Tamri, P.; Hemmati, A.; Boroujerdnia, M.G. wound healing properties of quince seed mucilage: In vivo evaluation in rabbit full-thickness wound model. Int. J. Surg. 2014, 12, 843-847. [CrossRef] [PubMed]

105. George, B.; Suchithra, T.V. Plant-derived bioadhesives for wound dressing and drug delivery system. Fitoterapia 2019, $137,104241$. [CrossRef]

106. Ahmad, S.; Ahmad, M.; Manzoor, K.; Purwar, R.; Ikram, S. A review on latest innovations in natural gums based hydrogels: Preparations \& applications. Int. J. Biol. Macromol. 2019, 136, 870-890. [CrossRef] [PubMed]

107. Bouyer, E.; Mekhloufi, G.; Rosilio, V.; Grossiord, J.L.; Agnely, F. Proteins, polysaccharides, and their complexes used as stabilizers for emulsions: Alternatives to synthetic surfactants in the pharmaceutical field? Int. J. Pharm. 2012, 436, 359-378. [CrossRef] [PubMed]

108. Campos, B.E.; Dias Ruivo, T.; da Silva Scapim, M.R.; Madrona, G.S.; Bergamasco, R.D. Optimization of the mucilage extraction process from chia seeds and application in ice cream as a stabilizer and emulsifier. LWT Food Sci. Technol. 2016, 65, 874-883. [CrossRef]

109. Ahuja, M.; Kumar, A.; Yadav, P.; Singh, K. Mimosa pudica seed mucilage: Isolation; characterization and evaluation as tablet disintegrant and binder. Int. J. Biol. Macromol. 2013, 57, 105-110. [CrossRef]

110. Kaleemullah, M.; Jiyauddin, K.; Thiban, E.; Rasha, S.; Al-Dhalli, S.; Budiasih, S.; Gamal, O.E.; Fadli, A.; Eddy, Y. Development and evaluation of Ketoprofen sustained release matrix tablet using Hibiscus rosa-sinensis leaves mucilage. Saudi Pharm. J. 2017, 25, 770-779. [CrossRef]

111. Chaudhary, A.; Kulkarnı, G.T.; Awasthı, R.; Kumar, P. Investigation on binding properties of Grewi asiatica mucilage in tablet formulations. Marmara Pharm. J. 2016, 20, 353-367. [CrossRef]

112. Raj, V.; Shim, J.J.; Lee, J. Grafting modification of okra mucilage: Recent findings, applications, and future directions. Carbohydr. Polym. 2020, 116653. [CrossRef]

113. Braghiroli, F.L.; Bouafif, H.; Neculita, C.M.; Koubaa, A. Activated biochar as an effective sorbent for organic and inorganic contaminants in water. Water Air Soil Pollut. 2018, 229-230. [CrossRef]

114. Hanjra, M.A.; Blackwell, J.; Carr, G.; Zhang, F.; Jackson, T.M. wastewater irrigation and environmental health: Implications for water governance and public policy. Int. J. Hyg. Environ. Health 2012, 215, 255-269. [CrossRef]

115. Rahman, Z.; Singh, V.P. The relative impact of toxic heavy metals (THMs) (arsenic (As), cadmium (Cd), chromium (Cr)(VI), mercury $(\mathrm{Hg})$, and lead $(\mathrm{Pb})$ ) on the total environment: An overview. Environ. Monit. Assess. 2019, 191, 419. [CrossRef] [PubMed]

116. Jones, B.O.; John, O.O.; Luke, C.; Ochieng, A.; Bassey, B.J. Application of mucilage from dicerocaryum eriocarpum plant as biosorption medium in the removal of selected heavy metal ions. J. Environ. Manag. 2016, 177, 365-372. [CrossRef]

117. Fox, D.I.; Pichler, T.; Yeh, D.H.; Alcantar, N.A. Removing heavy metals in water: The interaction of cactus mucilage and arsenate (As (V)). Environ. Sci. Technol. 2012, 46, 4553-4559. [CrossRef]

118. Anastasakis, K.; Kalderis, D.; Diamadopoulos, E. Flocculation behavior of mallow and okra mucilage in treating wastewater. Desalination 2009, 249, 786-791. [CrossRef]

119. Bouatay, F.; Eljebsi, N.; Dridi-Dhaouadi, S.; Mhenni, F. Valorization of the vicia faba mucilage on textile wastewater treatment as a bio-flocculant: Process development and optimization using response surface methodology (RSM). Water Sci. Technol. 2017, 75, 629-642. [CrossRef]

120. Sindhu, G.; Ratheesh, M.; Shyni, G.L.; Nambisan, B.; Helen, A. Anti-inflammatory and antioxidative effects of mucilage of Trigonella Foenum Graecum (fenugreek) on adjuvant induced arthritic rats. Int. Immunopharmacol. 2012, 12, 205-211. [CrossRef]

121. Ahmed, E.M. Hydrogel: Preparation, characterization, and applications: A review. J. Adv. Res. 2015, 6, 105-121. [CrossRef]

122. Sharma, G.; Naushad, M.; Kumar, A.; Rana, S.; Sharma, S.; Bhatnagar, A.; Stadler, F.J.; Ghfar, A.A.; Khan, M.R. Efficient removal of coomassie brilliant blue r-250 dye using starch/poly(alginic acid-cl-acrylamide) nanohydrogel. Process Saf. Environ. Prot. 2017, 109, 301-310. [CrossRef]

123. Lodhi, B.A.; Hussain, M.A.; Sher, M.; Haseeb, M.T.; Ashraf, M.U.; Hussain, S.Z.; Hussain, I.; Bukhari, S.N.A. Polysaccharide-based superporous, superabsorbent, and stimuli responsive hydrogel from sweet basil: A novel material for sustained drug release. Adv. Polym. Technol. 2019, 2119, 9583516. [CrossRef]

124. Setia, A.; Ahuja, P. Nanohydrogels. In Organic Materials as Smart Nanocarriers for Drug Delivery; Elsevier: Amsterdam, The Netherlands, 2018; pp. 293-368. [CrossRef]

125. Okutan, N.; Terzi, P.; Altay, F. Affecting parameters on electrospinning process and characterization of electrospun gelatin nanofibers. Food Hydrocoll. 2014, 39, 19-26. [CrossRef]

126. Fathi, M.; Martín, Á.; McClements, D.J. Nanoencapsulation of food ingredients using carbohydrate based delivery systems. Trends Food Sci. Technol. 2014, 39, 18-39. [CrossRef] 
127. Prusty, K.; Swain, S.K. Release of ciprofloxacin drugs by nano gold embedded cellulose grafted polyacrylamide hybrid nanocomposite hydrogels. Int. J. Biol. Macromol. 2019, 126, 765-775. [CrossRef]

128. Mohammadinejad, R.; Kumar, A.; Ranjbar-Mohammadi, M.; Ashrafizadeh, M.; Han, S.S.; Khang, G.; Roveimiab, Z. Recent advances in natural gum-based biomaterials for tissue engineering and regenerative medicine: A review. Polymers 2020, $12,176$. [CrossRef]

129. Thakur, V.K.; Thakur, M.K. Recent Trends in Hydrogels Based on Psyllium Polysaccharide: A Review. J. Clean. Prod. 2014, 82, 1-15. [CrossRef]

130. Rayegan, A.; Allafchian, A.; Abdolhosseini Sarsari, I.; Kameli, P. Synthesis and characterization of basil seed mucilage coated $\mathrm{Fe}_{3} \mathrm{O}_{4}$ magnetic nanoparticles as a drug carrier for the controlled delivery of cephalexin. Int. J. Biol. Macromol. 2018, 113, 317-328. [CrossRef] [PubMed]

131. Seyyed, M.; Tabrizi, H.M.; Behrouz, E.; Vahid, J. Biosynthesis of pure zinc oxide nanoparticles using Quince seed mucilage for photocatalytic dye degradation. J. Alloy. Compd. 2020, 821, 153519. [CrossRef]

132. Prasad, A.R.; Garvasis, J.; Oruvil, S.K.; Joseph, A. Improving oxidative and microbial stability of beef using Shahri Balangu seed mucilage loaded with Cumin essential oil as a bioactive edible coating. J. Phys. Chem. Solids 2019, 127, 265-274. [CrossRef]

133. Mahmoodi, M.; Javanbakht, V. Fabrication of Zn-based magnetic zeolitic imidazolate framework bionanocomposite using basil seed mucilage for removal of azo cationic and anionic dyes from aqueous solution. Int. J. Biol. Macromol. 2021, 167, 1076-1090. [CrossRef] [PubMed]

134. Pathak, D.; Kumar, P.; Kuppusamy, G.; Gupta, A.; Kamble, B.; Wadhwani, A. Physicochemical characterization and toxicological evaluation of plant-based anionic polymers and their nanoparticulated system for ocular delivery. Nanotoxicology 2014, 8, 843-855. [CrossRef] [PubMed]

135. Akbari, I.; Ghoreishi, S.M.; Habibi, N. Generation and precipitation of paclitaxel nanoparticles in basil seed mucilage via combination of supercritical gas antisolvent and phase inversion techniques. J. Supercrit. Fluids 2014, 94, 182-188. [CrossRef]

136. Haseeb, M.T.; Khaliq, N.U.; Yuk, S.H.; Hussain, M.A.; Bashir, S. Linseed polysaccharides based nanoparticles for controlled delivery of docetaxel: Design, in vitro drug release and cellular uptake. J. Drug Deliv. Sci. Technol. 2019, 49, 143-151. [CrossRef]

137. Chawla, P.; Kumar, N.; Kaushik, R.; Dhull, S.B. Synthesis, characterization and cellular mineral absorption of nanoemulsions of Rhododendron arboreum flower extracts stabilized with gum Arabic. J. Food Sci. Technol. 2019, 56, 5194-5203. [CrossRef]

138. Carmona, J.C.; Robert, P.; Vergara, C.; Sáenz, C. Microparticles of yellow-orange cactus pear pulp (Opuntia ficus-indica) with cladode mucilage and maltodextrin as a food coloring in yogurt. LWT 2021, 138, 110672. [CrossRef]

139. Miart, F.; Fournet, F.; Dubrulle, N.; Petit, E.; Demailly, H.; Dupont, L.; Zabijak, L.; Marcelo, P.; Boudaoud, A.; Pineau, C.; et al. Cytological approaches combined with chemical analysis reveals the layered nature of flax mucilage. Front. Plant Sci. 2019, 10, 684. [CrossRef]

140. Waghmare, R.; Moses, J.A.; Anandharamakrishnan, C. Mucilages: Sources, extraction methods, and characteristics for their use as encapsulation agents. Crit. Rev. Food Sci. Nutr. 2021, 1-22. [CrossRef]

141. Soto-Cerda, B.J.; Cloutier, S.; Quian, R.; Gajardo, H.A.; Olivos, M.; You, F.M. Genome-wide association analysis of mucilage and hull content in flax (Linum usitatissimum L.) seeds. Int. J. Mol. Sci. 2018, 19, 2870. [CrossRef]

142. Orrego, D.; Zapata-Zapata, A.D.; Kim, D. Optimization and scale-up of coffee mucilage fermentation for ethanol production. Energies 2018, 11, 786. [CrossRef]

143. Añibarro-Ortega, M.; Pinela, J.; Barros, L.; Ćirić, A.; Silva, S.P.; Coelho, E.; Mocan, A.; Calhelha, R.C.; Soković, M.; Coimbra, M.A.; et al. Compositional features and bioactive properties of aloe vera leaf (Fillet, mucilage, and rind) and flower. Antioxidants 2019, 8, 444. [CrossRef] [PubMed]

144. Allegra, A.; Sortino, G.; Inglese, P.; Settanni, L.; Todaro, A.; Gallotta, A. The effectiveness of Opuntia ficus-indica mucilage edible coating on post-harvest maintenance of ‘Dottato'fig (Ficus carica L.) fruit. Food Packag. Shelf Life 2017, 12, 135-141. [CrossRef] 